\title{
DISFUNGSI INSTITUSI KONSERVASI DAN DAMPAKNYA PADA KEGAGALAN ADOPSI TEKNOLOGI KONSERVASI TANAH DAN AIR, STUDI KASUS DI KABUPATEN WONOGIRI DAN TEMANGGUNG, JAWA TENGAH (Dysfunction of Conservation Institutions and its Impacts on the Failures of Soil and Water Conservation Technologies Adoption, Case Study at Wonogiri and Temanggung Regencies, Central Java Province)
}

\author{
Nana Haryanti \\ 'Balai Penelitian Kehutanan Solo. Jl. A. Yani PO Box 295 Pabelan \\ Telepon/Fax.: (+62 271) 716709/716959 \\ E-mail : nana_haryanti@yahoo.com
}

Diterima 13 Agustus 2013, direvisi 25 November 2013, disetujui 10 Desember 2013

\begin{abstract}
Low rate adoption of soil and water conservation technologies, such as agroforestry systems and terrace farming, is still prevalent in a number of areas proned to water erosion. One of prominence alleged factors is conservation institution, which is mostly weak in inducing community, especially farmers or landholders, to apply soil and water conservation technologies to their own farmland. By using two case studies of soil and water conservation projects in Wonogiri and Temanggung regencies, this paper is aimed to explore and analyze the role of conservation institutions in the diffusion process of soil and water conservation technologies among farmers or landholders. Data were collected using in-depth interviews and focus group discussions. Institution in this research referred to institutional framework. developed by Department of Foreign and International Development (DFID). They included formal conservation institutions, namely forest farmer groups, government institution, and extension agents. Results showed that the absence of conservation institutions discouraged farmers' motivation to adopt conservation technologies. Institutional dysfunction resulted in breaking of social learning processes thus decreasing community awareness and decompressing conservation norms. As an implication of this study, governmentpolicies on soil conservation and land rehabilitation should be adjusted to be more farmers or landholders oriented and should include incentives and disincentives for soil conservation and land rehabilitation activities.
\end{abstract}

Keywords: Technology, adoption, conservation, institution

ABSTRAK

Adopsi teknologi konservasi tanah dan air, seperti sistem agroforestri dan penerasan lahan, sejauh ini masih rendah. Salah satu yang diduga kuat menjadi faktor penyebabnya adalah masih lemahnya atau bahkan tidak tersedianya institusi (lembaga) yang mampu mendorong masyarakat, khususnya petani, agar menerapkan teknologi konservasi tanah dan air. Makalah ini ditujukan untuk mengeksplorasi, menganalisis dan menjelaskan peran institusi konservasi dalam proses difusi teknologi konservasi tanah dan air. Penelitian dilakukan dengan menggunakan pendekatan kualitatif. Data yang digunakan dalam analisis diperoleh melalui wawancara mendalam dan diskusi kelompok terhadap kelompok petani dan sejumlah pihak yang terkait dengan konservasi tanah dan air. Lokasi penelitian adalah kabupaten Wonogiri dan Temanggung, dan dua kelompok tani hutan dipilih sebagai kelompok informan pada penelitian ini. Institusi dalam penelitian ini adalah institusi yang merujuk pada kerangka yang dikembangkan Department of Foreign and Internatioanl Development (DFID) berupa lembaga formal konservasi meliputi kelompok tani hutan, lembaga pemerintah yaitu dinas kehutanan dan penyuluh. Hasil penelitian menunjukkan bahwa ketiadaan institusi konservasi menghambat petani melakukan adopsi teknologi konservasi. Disfungsi intitusi juga mengakibatkan tidak berjalannya proses belajar sosial sehingga melemahkan kesadaran masyarakat dan hilangnya norma-norma konservasi. Sebagai implikasi dari temuan tersebut, maka kebijakan pemerintah yang terkait dengan konservasi tanah dan rehabilitasi lahan perlu dirancang sedemikian rupa sehingga berpihak kepada pelaku konservasi dan mengandung insentif dan disinsentif bagi kegiatan-kegiatan konservasi.

Kata kunci: Teknologi, adopsi, konservasi, institusi 


\section{PENDAHULUAN}

Degradasi lahan sebagai akibat dari masih rendahnya adopsi teknologi konservasi tanah dan air merupakan salah satu permasalahan lingkungan yang sampai saat ini masih memerlukan penyelesaian, terutama dalam upaya pelestarian daerah aliran sungai (DAS). Teknologi konservasi air dan tanah sebagai salah satu cara yang digunakan untuk melestarikan kesuburan produktivitas lahan sebenarnya telah banyak diketahui oleh petani. Namun demikian, upaya mempromosikan teknologi konservasi agar diadopsi secara luas oleh masyarakat petani masih belum memberikan hasil yang memuaskan. Rendahnya keberhasilan upaya perluasan praktik konservasi pada masyarakat petani menurut Shiferaw et al. (2009), Agrawal dan Perrin (2008) salah satunya disebabkan oleh lemahnya lembaga (institusi) sosial yang terkait dengan pelestarian sumberdaya alam. Shifferaw et al. (2009) menjelaskan bahwa institusi mampu mengkondisikan petani untuk melakukan inovasi, adopsi dan adaptasi teknologi konservasi air dan tanah yang dipilihnya. Oleh karena itu, Bromley (2008) berpendapat bahwa pada masyarakat petani yang tidak memiliki institusi yang baik, hampir dapat dipastikan investasi di bidang konservasi cenderung sangat rendah atau bahkan tidak dilakukan.

Kesadaran terhadap pentingnya peran institusi dalam menunjang keberhasilan program-program konservasi tanah dan air sudah lama tumbuh pada masyarakat konservasi di Indonesia. Meskipun demikian, pembinaan intensif yang dilakukan pada institusi konservasi baik di tingkat petani, seperti kelompok tani hutan, desa maupun pemerintah daerah, masih jarang dilakukan karena berbagai alasan seperti tidak tersedianya anggaran, tenaga ahli dan sebagainya. Akibatnya, lembaga-lembaga tersebut belum mampu berperan menjadi agent of change, terutama untuk mengubah perilaku petani agar menerapkan teknik konservasi yang baik pada lahan garapannya.

Pendekatan lama, yakni top-down interventions, yang semula digunakan sebagai metode alih teknologi konservasi memang telah banyak ditinggalkan, tetapi masyarakat konservasi di Indonesia sejauh ini belum beranjak dari pendekatan populist atau farmer-first approach. Pendekatan tersebut menekankan bottom-up participatory interventions, tetapi hanya memfokuskan pada kegiatan individu petani. Pendekatan populist belum mempertimbangkan aspek yang lebih luas, seperti adanya fakta yang menunjukkan bahwa keputusan petani untuk mengadopsi teknik konservasi sangat dipengaruhi oleh kondisi ekonomi, kelembagaan dan kebijakan atau politik (Robbins \& Williams, 2005). Oleh karena itu, perhatian terhadap peningkatan kapasitas lembaga atau institusi konservasi yang dipandang mampu mendorong terjadinya percepatan adopsi teknik konservasi seperti kelompok tani hutan, penyuluh, dan dinas terkait, pada suatu kelompok masyarakat pengguna lahan, khususnya petani, sangatlah perlu dilakukan sebagaimana dikembangkan melalui pendekatan neo-liberal. Pendekatan ini menganjurkan perlunya memberikan perhatian pada kendala-kendala yang muncul berkaitan dengan kelembagaan baik itu organisasinya maupun aturan yang ada agar konservasi secara ekonomi menguntungkan dan menjadi atraktif bagi petani. Institusi dipercaya mampu membangkitkan tindakan bersama (collective action) untuk mendorong investasi bersama agar masalah sumberdaya alam bisa terselesaikan dengan lebih mudah (Shiferaw et al., 2009).

Mekanisme pengembangan dan penyebaran informasi mengenai alternatif teknologi yang disarankan sangat penting dalam proses adopsi teknologi konservasi. Pada proses ini, institusi memainkan peranan penting pada semua tingkatan (Lee, 2005). Pada tingkatan rumah tangga, keputusan untuk mengadopsi suatu teknologi seringkali dipengaruhi oleh kelompok (tetangga). Petani mengembangkan jaringan sosialnya untuk mencari informasi sebelum melakukan uji coba suatu teknologi baru. Disinilah kelompok tani hutan seringkali berperan memberikan arahan kepada petani untuk mengadopsi atau tidak mengadopsi teknologi yang disarankan. Oleh karena itu, persepsi kelompok tani hutan terhadap suatu teknologi konservasi memiliki peran sentral. Ketika kelompok tani hutan memiliki persepsi positif terhadap suatu teknologi konservasi, maka hampir dapat dipastikan persepsi tersebut berpengaruh positif pada proses pengambilan keputusan petani dalam mengadopsi atau tidak mengadopsi suatu teknologi konservasi. Pada tingkat pengambil kebijakan, cara melakukan promosi program-program konservasi yang dirancang oleh para pengambil kebijakan serta karakteristik dari penyuluh seringkali sangat 
menentukan diadopsi atau tidak diadopsinya suatu teknologi konservasi oleh petani (Pannell et al., 2006).

Namun demikian, pada kelompok masyarakat yang memiliki disfungsi institusi, proses adopsi cenderung berjalan lambat. Menurut Cramb (2004), hal tersebut terjadi karena masyarakat tersebut tidak dapat memanfaatkan modal sosial (social capital) yang dimilikinya. Modal sosial memungkinkan suatu kelompok masyarakat secara kolektif bekerja bersama-sama, terutama dalam menghadapi kemungkinan munculnya resiko akibat penerapan teknologi yang disarankan. Tanpa institusi yang effisien, petani harus menanggung sendiri setiap biaya transaksi yang timbul sebagai akibat dari kegiatan pengelolaan lahannya. Untuk itu, Nuryanti dan Swastika (2011) menyarankan perlunya suatu kajian mengenai peran kelompok tani dalam percepatan penerapan teknologi konservasi. Doss (2006) juga menyatakan isu tersebut masih belum terjawab, terutama pada pertanyaan tentang "sejauh mana peran institusi dan kebijakan dalam memengaruhi adopsi teknologi konservasi?”.

Makalah ini bertujuan menjelaskan konsekuensi yang muncul ketika suatu teknologi atau inovasi konservasi tanah dan air diberikan kepada suatu kelompok tani yang pasif organisasinya dan tidak berjalan, serta dengan kegiatan penguatan kelompok yang minim dari peneliti. Analisis yang dilakukan juga mencakup peran lembaga seperti dinas terkait atau pengambil kebijakan dan penyuluh pada keberhasilan difusi teknologi konservasi tanah dan air.

\section{METODE PENELITIAN}

\section{A. Waktu dan Lokasi Penelitian}

Penelitian dilakukan pada kelompok tani hutan Dadi Rejo, Desa Pulutan Wetan, Kecamatan Wuryantoro, Kabupaten Wonogiri dan kelompok tani hutan Wonosari I, Desa Wonosari, Kecamatan Bulu, Kabupaten Temanggung. Pada lokasi tersebut telah dilakukan kegiatan penelitian secara partisipasi (participatory research) berupa pembuatan bangunan konservasi tanah dan air, yaitu penerasan lahan (terasering) dan penanaman tanaman kayu dan buahbuahan dengan sistem agroforestri pada lahan petani.
Penelitian konservasi tanah dan air secara partisipasi di desa Pulutan dilakukan pada tahun 2010-2011, sedangkan penelitian di desa Wonosari dilakukan sejak tahun 2009-sekarang. Kegiatan penelitian tersebut dimaksudkan agar petani peserta plot demonstrasi (demplot) dan petani di sekitarnya mengadopsi teknologi konservasi tanah dan air yang dikembangkan secara partisipasi selama penelitian dilakukan, sedangkan penelitian mengenai institusi yang menunjang makalah ini dilakukan pada pada tahun 2011 untuk desa Pulutan Wetan dan 2010-2012 untuk desa Wonosari.

\section{B. Bahan dan Alat Penelitian}

Bahan yang digunakan dalam penelitian ini antara lain berupa kuesioner semi terbuka dan panduan diskusi. Kuesioner berisi pertanyaanpertanyaan yang diajukan kepada responden pada proses wawancara. Panduan diskusi berisi topik-topik yang akan dibahas dalam diskusi kelompok. Alat perekam, catatan lapangan dan kamera disiapkan agar kegiatan wawancara berjalan dengan lancar. Kegiatan diskusi kelompok dilengkapi dengan peralatan papan tulis, spidol, kertas plano, kertas metaplan, laptop untuk presentasi, proyektor, alat perekam dan kamera.

\section{Metode Penelitian Kualitatif}

Metode penelitian yang digunakan adalah metode kualitatif dengan pertimbangan bahwa metode tersebut mampu menjelaskan dengan lebih baik mengenai isu-isu penting berkaitan dengan institusi (kelembagaan) konservasi. Penelitian kualitatif memiliki fleksibilitas tinggi sehingga peneliti bisa mengembangkan pertanyaan lebih luas dan bisa menggali informasi mendalam yang sering kali tidak secara jelas muncul dalam proses wawancara maupun diskusi kelompok. Hal ini karena topik mengenai kelembagaan sangat dinamis, seringkali melibatkan proses politik yang tidak mudah dijelaskan oleh responden. Studi kasus dilakukan pada dua kelompok tani hutan, untuk mendapatkan gambaran fenomena yang mungkin bisa digeneralisasi dari keduanya.

Institusi yang dimaksud dalam makalah ini merujuk kepada kerangka (framework) institusi yang 
dikembangkan oleh The Department for International Development (DFID) (Matsaert, 2002). Institusi adalah organisasi dan/atau seperangkat aturan, kebijakan, atau perundangan yang mengatur perilaku sosial. Institusi menurut konsep DFID bekerja pada semua tingkatan mulai dari rumah tangga sampai internasional dan pada semua bidang baik privat maupun publik (Matsaert, 2002). Definisi operasional institusi untuk penelitian ini adalah organisasi formal yaitu kelompok tani hutan, penyuluh dan lembaga negara seperti dinas yang terkait dengan kegiatan konservasi.

Pengumpulan data dilakukan dengan wawancara mendalam dan focus group discussion (FGD). Wawancara mendalam dilakukan kepada anggota kelompok tani hutan, staf dinas kehutanan, penyuluh dan tokoh masyarakat setempat. Jumlah responden adalah 18 orang anggota kelompok tani hutan Dadi Rejo peserta demplot penelitian, 5 orang anggota kelompok tani hutan Dadi Rejo bukan peserta demplot penelitian, 3 orang anggota kelompok tani hutan Wonosari I peserta plot penelitian, 23 orang anggota kelompok tani hutan Wonosari I bukan peserta plot penelitian, 2 orang penyuluh dan 1 staf dinas kehutanan. Sebagai alat triangulasi data dilakukan FGD untuk mendapatkan pemahaman yang lebih luas mengenai topik yang diteliti, meningkatkan validitas hasil penelitian dan menghindari munculnya data yang tidak relevan yang bisa mengakibatkan bias pada penelitian.

Analisa data dilakukan dengan cara menempatkan data yang diperoleh sesuai kategori yang telah dibuat sebelumnya. Kemudian dilihat pola dan hubungan data dalam kategori yang sama. Pada tahapan ini persamaan dan perbedaan pandangan responden terhadap suatu fenomena dikelompokkan kemudian diambil suatu kesimpulan. Langkah selanjutnya adalah mencari pola dan hubungan data antara kategori yang satu dengan yang lain untuk mendapatkan suatu gambaran mengenai kategori yang penting atau dominan dan kurang penting.

Langkah terakhir adalah interpretasi data. Interpretasi data dilakukan dengan cara mencari makna dan signifikansi dari data yang terkumpul untuk kemudian ditarik suatu kesimpulan.

\section{HASIL DAN PEMBAHASAN}

\section{A. Dinamika Pada Penelitian untuk Pe- ngembangan Konservasi Tanah dan Air}

Penentuan lokasi kegiatan penelitian untuk pengembangan konservasi tanah dan air secara partisipasi (participatory research) yang dilakukan di Wonogiri dan Temanggung dengan membuat bangunan teras dan tanaman agroforestri dilakukan terutama pada pertimbangan fisik lahan dengan lereng miring yang terjal. Kegiatan pertanian yang dilakukan pada lahan dengan lereng miring yang terjal berpotensi menyebabkan terjadinya erosi. Oleh sebab itu dilakukan kegiatan pencegahan dengan cara membuat teras dan menanam tanaman kayu dan buah pada batas-batas lahan. Kegiatan penelitian konservasi tanah dan air tersebut dilakukan dengan metode partisipasi, yaitu dengan meminta petani untuk terlibat secara suka rela pada kegiatan penelitian. Beberapa petani dengan lahan ideal untuk kegiatan penelitian, yaitu yang berlokasi pada lereng terjal dan dilakukan pertanian intensif pada lahan tersebut diminta untuk membantu kegiatan penelitian, dan digunakan lahan garapannya sebagai demplot uji coba. Pada proses sosialisasi, dijelaskan bahwa selama penelitian berlangsung petani masih memiliki keleluasaan untuk menanam tanaman pertanian seperti yang biasa mereka lakukan.

Namun demikian, beberapa catatan yang menjadi kelemahan dari kegiatan penelitian untuk pengembangan konservasi tanah dan air, dan kemudian ikut berkontribusi pada rendahnya adopsi teknik konservasi air dan tanah yang diperkenalkan adalah:

1. Pemilihan kelompok tani berdasar lokasi demplot

Pemilihan lokasi yang ideal untuk mendukung kegiatan penelitian konservasi tanah dan air, berdampak pada pemilihan kelompok tani hutan. Anggota peserta demplot penelitian konservasi tanah dan air harus dipilih menjadi kelompok binaan dengan maksud agar hasil penelitian dapat diadopsi petani demplot penelitian serta anggota kelompok yang lain. Metode ini tidak memungkinkan peneliti untuk memilih kelompok tani yang sudah maju organisasinya dan harus bekerja dengan kelompok yang ada, meskipun kelompok tani tersebut tidak berjalan. 
2. Kegiatan penguatan kelompok tidak dilakukan secara intensif

Kegiatan penyuluhan dilakukan oleh peneliti, untuk memberikan pemahaman kepada petani yang lahannya dimanfaatkan sebagai demplot uji coba maupun kepada anggota kelompok tani hutan yang lain. Penyuluhan berisi manfaat teras dan tanaman agroforestri. Pada kesempatan tertentu penyuluh diundang untuk turut melakukan penyuluhan yang mendukung kegiatan penelitian. Namun penguatan kelompok hingga menjadi kelompok tani yang maju, terutama maju dalam perilaku bertani yang ramah lingkungan membutuhkan waktu yang lama, bahkan bisa memakan waktu tahunan, sedangkan penelitian konservasi tanah dan air ini dibatasi waktu, sehingga pembuatan demplot penelitian segera dilakukan menyusul pendampingan kelompok. Hal ini maksudkan agar penelitian segera mendapatkan manfaat secara fisik berupa data penurunan erosi maupun sosial berupa tanggapan petani atas demplot penelitian.

Namun, pada kelompok yang masih pasif seperti kelompok tani hutan Dadi Rejo dan Wonosari I kegiatan penguatan kelompok dan menjadikannya organisasi yang maju dalam pengetahuan maupun perilaku bertani yang sesuai kaidah konservasi tanah dan air mutlak diperlukan, tetapi tidak bisa dilakukan dalam waktu singkat. Ketika kelompok tani tersebut belum benar-benar menjadi organisasi yang maju, maka pengenalan teknologi konservasi air dan tanah kemudian menghadapi berbagai kendala.

3. Proses sosialisasi searah

Sebagai upaya menyukseskan kegiatan penelitian, peneliti selalu mengomunikasikan kepada petani peserta demplot penelitian mengenai langkah yang akan ditempuh peneliti dan perlakuan yang akan diterapkan pada lahan garapan mereka. Pada proses sosialisasi ini, komunikasi hanya berjalan searah saja dari peneliti kepada petani. Pengamatan lapangan memperlihat bahwa para petani terlihat enggan mengemukakan pendapat, atau menyanggah penjelasan yang diberikan peneliti terutama mengenai pentingnya tanaman agroforestri untuk mencegah erosi. Fenomena ini sangat mencolok terlihat pada kelompok tani hutan Dadi Rejo. Pada kelompok Wonosari I, juga hanya beberapa petani saja terlihat lebih berani mengemukakan pendapat. Proses seperti ini menyebabkan diskusi untuk saling memberi masukan baik dari peneliti kepada petani maupun sebaliknya dari petani kepada peneliti menjadi tidak berjalan dengan baik.

4. Pemilihan orang kunci (key person) yang tidak dilakukan secara cermat

Keterbatasan waktu dan pengetahuan mengenai kondisi masyarakat setempat menyebabkan peneliti sering kali kurang tepat memilih orang kunci. Akibatnya orang kunci yang dipilih belum mampu menjadi agen yang bisa memotivasi anggota kelompok yang lain untuk berubah. Orang kunci tersebut juga belum mampu menyampaikan pesan dan pengetahuan pada anggota kelompok yang lain. Dengan demikian diskusi oleh petani terutama mengenai pengembangan kegiatan konservasi tanah dan air tidak berlangsung.

5. Metode pendekatan personal yang minim dilakukan

Menghadapi berbagai kendala yang muncul dalam proses penelitian, peneliti berusaha mengatasi dengan melakukan pendekatan pribadi. Pendekatan pribadi terutama dilakukan kepada petani yang melakukan berbagai penolakan terhadap perlakuan peneliti pada demplot penelitian. Namun kurang intensifnya pendekatan pribadi yang dilakukan mengakibatkan berbagai kendala seperti penolakan petani, tidak selalu bisa diselesaikan.

\section{B. Institusi di Tingkat Petani}

Salah satu contoh institusi di tingkat petani adalah kelompok tani hutan. Kelompok tani hutan adalah kumpulan petani yang secara formal terikat karena memiliki kepentingan yang sama. Kelompok tani mulai dibentuk pada 1979 ketika program Intensifikasi Khusus (Insus) diluncurkan (Nuryanti \& Swastika, 2011). Terbentuknya kelompok tani hutan pada umumnya dilatarbelakangi oleh pelaksanaan suatu proyek oleh pemerintah, meskipun secara alami petani akan selalu berusaha membentuk suatu kelompok sosial untuk mendiskusikan cara mereka melakukan pengelolaan lahan dan menjalankan usaha pertanian-kehutanannya. Melalui kelompok sosial tersebut sering kali teknologi dan inovasi pertanian dipelajari dan ditularkan kepada petani 
anggota sebagai suatu bentuk penyuluhan informal (McKell \& Peiretti, 2004). Di sinilah difusi inovasi berlangsung, yaitu suatu proses mengomunikasikan inovasi menggunakan saluran tertentu yang dilakukan dari waktu ke waktu kepada anggota suatu sistem sosial (Rogers, 2003).

Pengamatan terhadap kelompok tani hutan Dadi Rejo dan Wonosari I, memperlihatkan fenomena dimana difusi inovasi teknologi konservasi tanah dan air yang diperkenalkan para peneliti tidak bisa berjalan. Salah satu yang diduga kuat menjadi penyebabnya adalah belum berperannya kelompok tani hutan sebagai katalisator. Proses difusi suatu inovasi membutuhkan suatu sarana atau merujuk pada Roger (2003) membutuhkan saluran agar inovasi tersebut bisa disebarluaskan, kemudian didiskusikan keunggulan dan kelemahannya sebelum diterapkan, dan selanjutnya diambil suatu keputusan mengadopsi atau tidak mengadopsi. Sarana yang dibutuhkan untuk proses difusi inovasi sampai dengan adopsi yang paling tepat bagi masyarakat petani adalah kelompok tani hutan.

Kelompok tani hutan Dadi Rejo dan Wonosari I belum berfungsi dengan baik, maka proses adopsi teknologi konservasi tanah dan air yang diperkenalkan peneliti, belum terjadi seperti yang diharapkan. Petani masih menolak membangun teras dan beberapa tanaman kayu dan buah yang ditanam di demplot penelitian sengaja dirusak. Petani dari kelompok tani hutan Dadi Rejo yang lahannya digunakan sebagai dempot penelitian selalu menanyakan kapan kegiatan penelitian berakhir, karena mereka menginginkan tanaman agroforestri yang ditanam peneliti segera dicabut. Beberapa hal yang menjadi penyebab tidak berfungsinya kelompok tani Dadi Rejo dan Wonosari I adalah:

1. Minimnya pendampingan kelompok oleh tim peneliti mengakibatkan kedua kelompok tani hutan tidak mampu meningkatkan kinerja organisasi kelompok tani. Kelompok tani hutan pada akhirnya belum bisa menjadi agen perubah perilaku untuk mendukung pola pengelolaan lahan pertanian yang ramah lingkungan.

2. Selama ini anggota kelompok tani tidak secara aktif memanfaatkan organisasi sebagai sarana sosial untuk saling berkomunikasi, tidak ada pertemuan kelompok dan kegiatan. Hanya merupakan nama yang dibuat pada masa program penghijauan dan Insus diluncurkan.
Pada kondisi ini pertemuan kelompok yang selalu dilakukan peneliti, belum mampu menjadi contoh dan menghidupkan kembali organisasi yang sudah ada.

Disfungsi institusi kelompok tani Dadi Rejo dan Wonosari I pada akhirnya mengakibatkan kelompok tidak mampu memberikan fasilitas bagi berjalannya (1) diseminasi atau komunikasi, (2) pembelajaran sosial (social learning), (3) tindakan bersama (collective action), (4) adaptasi, (5) pemanfaatan modal sosial (social capital) secara efisien (untuk mengurangi biaya transaksi), yang merupakan prasyarat bagi terjadinya proses adopsi konsevasi tanah dan air (Doss, 2006; Cramb,2004).

1. Diseminasi atau Komunikasi

Pada saat ini kelompok tani hutan dipercaya sebagai sarana yang paling efektif yang bisa digunakan sebagai sarana penyebaran teknologi konservasi agar memberikan dampak signifikan. Kelompok dipandang sebagai motor bagi kegiatan penyuluhan berbasis masyarakat (Franzel et al., 2001). Penyuluhan adalah sarana untuk menyampaikan berbagai informasi yang relevan dengan kegiatan pertanian/kehutanan, seperti teknologi pengendalian erosi tanah dan air.

Diseminasi atau komunikasi inovasi pengendalian erosi dengan teras dan agroforestri di antara petani peserta dan petani di sekitar demplot penelitian tidak berlangsung. Proses diseminasi di antara anggota tidak dapat berjalan karena selama ini petani belum pernah mengelola kelompok tani hutan sebagai organisasi untuk mengembangkan pengetahuan di bidang pertanian dan kehutanan. Kelompok tani hutan belum dimanfaatkan sebagai sumber informasi dan alat untuk mempromosikan kegiatan, pengetahuan mengenai teknik dan usaha pertanian dan kehutanan, informasi pasar komoditas pertanian dan kehutanan dan sebagainya. Sebagai akibatnya, sebagian besar petani belum bisa merasakan manfaat menjadi anggota kelompok tani hutan. Anjuran peneliti untuk menghidupkan dan memanfaatkan kelompok tani hutan sebagai wahana untuk saling bertemu dan berdiskusi masalah pertanian dan kehutanan belum mampu menggerakkan partisipasi anggota.

Teknologi konservasi akan berdampak positif jika disebarkan secara horizontal di antara 
petani sendiri. Farmer-led extension atau penyuluhan dari dan untuk petani, adalah suatu paradigma baru yang mulai dikembangkan sebagai respon atas kegagalan metode penyuluhan tradisional yang dikembangkan yaitu dari pakar teknologi kepada petani (Akinnagbe \& Ajayi, 2010; Swanson, 2008). Namun demikian, ketidaksiapan institusi kelompok tani hutan Dadi Rejo dan Wonosari I kemudian menjadi penghambat bagi berjalannya proses diseminasi teknologi konservasi secara luas kepada petani. Metode penyuluhan tradisional sendiri juga gagal diterapkan pada kedua kelompok tani hutan tersebut. Hal ini terbukti dari terjadinya penolakan beberapa anggota petani peserta demplot penelitian untuk terus terlibat pada kegiatan penelitian. Agrawal dan Gibson (1999) dalam makalahnya mengingatkan bahwa konservasi memang lebih sulit diintroduksi kepada suatu masyarakat jika dilakukan oleh orang di luar komunitas. Pada kasus ini peneliti masih dianggap sebagai masyarakat luar sehingga masih sulit untuk mendorong petani mengikuti saran peneliti.

Kendala dalam proses diseminasi horizontal pada kelompok tani hutan Dadi Rejo dan Wonosari I dipengaruhi oleh faktor berikut ini:

(a) Kelompok belum memiliki agen pelopor yang bisa menjadi motivator bagi petani lain untuk meniru, dan memberikan arahan serta penjelasan manakala petani menghadapi kebimbangan atas putusan untuk mengadopsi teknik konservasi atau tidak. Orang kunci yang dipilih peneliti belum mampu menjadi agen perubahan, karena membentuk seseorang menjadi agen perubah juga membutuhkan ketrampilan khusus dan tidak mudah.

(b) Kelompok belum memiliki kegiatan rutin berkaitan dengan pertanian dan kehutanan sehingga diskusi mengenai hal tersebut sangat jarang dilakukan. Rendahnya intensitas diskusi dan komunikasi diantara anggota kelompok tani hutan Dadi Rejo dan Wonosari I salah satu penyebabnya adalah penyebaran lokasi lahan pertanian anggota kelompok (spatial dispersion), sehingga permasalahan usaha tani, apalagi masalah konservasi sangat jarang menjadi perhatian bersama.

(c) Spatial dispersion lahan pertanian juga mengakibatkan permasalahan pada setiap lahan berbeda-beda berkaitan dengan perbedaan topografi lahannya. Sebagian petani memiliki lahan pada lokasi dengan kelerengan curam, sementara yang lainnya pada lokasi-lokasi agak datar atau bahkan datar. Karena erosi hanya terjadi pada lahan dengan kelerengan curam, maka tidak semua anggota kelompok tani hutan tertarik untuk berdiskusi dan mencoba memecahkan permasalahan tersebut. Padahal jika tidak dikelola dengan baik, kegiatan pertanian pada lahan miring dapat berdampak negatif seperti longsor. Longsor sangat merugikan petani yang bercocok tanam pada lokasi dibawahnya. Oleh sebab itu kegiatan pertanian pada lahan miring dengan kelerengan curam, jika tidak dilakukan secara hati-hati dapat merugikan siapa saja baik petani yang bertani pada lahan miring sendiri maupun petani dibawahnya yang berlahan datar.

(d) Erosi bukanlah isu penting bagi petani. Menurut mereka erosi tanah tidak secara langsung memengaruhi produksi. Hal yang berbeda ketika petani dihadapkan pada permasalahan serangan hama dan penyakit tanaman atau organisme pengganggu tanaman (OPT). Bagi mereka, serangan OPT jauh lebih serius dan tampak nyata dibandingkan erosi tanah. Temuan serupa juga diperoleh pada sejumlah penelitian adopsi teknologi konservasi tanah dan air di sejumlah tempat di Indonesia dan negara-negara berkembang lainnya (Shiferaw et al., 2009). Oleh karena itu, hampir semua petani di lokasi penelitian tidak merasa perlu menempatkan erosi tanah sebagai prioritas utama permasalahan pertanian yang harus didiskusikan. Petani peserta demplot penelitian bahkan langsung memberikan respon negatif manakala tanaman agroforestri, khususnya tanaman kayu, ditanam pada lahan garapannya, karena merasa khawatir akan mengganggu produktivitas tanaman pertaniannya, khususnya tanaman pangan semusim. Salah satu pertimbangan utama petani adalah resiko kerugian usahataninya karena menanam tanaman kayu yang umumnya baru dapat dipanen ketika berumur di atas 5 tahun. Pada tahapan tersebut, kelompok tani hutan tidak berperan dalam memberikan arahan dan pertimbangan mengenai keuntungan agroforestri pada pelestarian sumberdaya lahan. Kondisi ini terjadi karena peneliti belum bisa mengembangkan kelompok tani hutan Dadi 
Rejo dan Wonosari I menjadi kelompok yang mampu menganalisis masalah (think tank) dan memberikan pemahaman pada petani anggota.

2. Pembelajaran Sosial (SocialLearning)

Pembelajaran sosial merupakan suatu proses penting dalam upaya pengelolaan sumber daya alam. Pada proses pembelajaran sosial, pengetahuan dan informasi diproduksi dan direproduksi untuk mendapatkan pemahaman bersama mengenai suatu masalah, kemudian pertimbangan-pertimbangan dilakukan sebelum akhirnya sampai pada suatu keputusan untuk melakukan perubahan perilaku (Muro \& Jeffery, 2008; Rist et al., 2006). Agar pembelajaran sosial dapat terjadi, perlu adanya suatu institusi yang menjadi payung dan bisa memberikan fasilitas bagi berlangsungnya pembelajaran sosial yaitu kelompok tani hutan. Hal ini karena proses pembelajaran sosial membutuhkan komunikasi dan interaksi sejumlah aktor agar bisa menghasilkan suatu outcome seperti regenerasi ilmu pengetahuan, teknologi dan keterampilan yang dibutuhkan petani (Muro \& Jeffery, 2008). Interaksi di antara petani bahkan dengan penyuluh dan peneliti akan lebih efektif jika dilakukan melalui kelompok tani, karena diskusi akan berjalan lebih dinamis dan lebih berdampak luas. Pada proses pembelajaran ini kelompok dapat berperan dengan cara memberikan fasilitas berlangsungnya pencarian bersama teknik-teknik pengelolaan sumberdaya alam agar lebih lestari.

Kelompok tani hutan Dadi Rejo dan Wonosari I belum dikelola sebagai suatu organisasi yang bisa mengatur suatu kegiatan pembelajaran bagi anggotanya, maka akibatnya pembelajaran sosial tidak berlangsung. Salah satu dampaknya adalah pengetahuan dan informasi penting berkaitan dengan kegiatan pertanian, kehutanan dan konservasi tidak dimiliki anggota. Upaya untuk meningkatkan kemampuan petani melakukan investigasi dan menganalisis permasalahan alam sebagai akibat pengelolaan sumber daya, kemudian belajar dan berinovasi untuk meningkatkan kualitas praktek pengelolaan lahan sesuai kaidah konservasi yang baik tidak berjalan.

Pembelajaran sosial pada hakekatnya bertujuan untuk meningkatkan kemampuan petani dalam menganalisis cara mereka dalam melakukan pengelolaan lahan dan melakukan sistem produksi usaha tani dan kehutanan. Kegagalan Kelompok Dadi Rejo dan Wonosari I memberikan fasilitas bagi berjalannya pembelajaran sosial juga mengakibatkan anggota kelompok termasuk para petani peserta demplot penelitian tidak dapat mengidentifikasi terjadinya erosi yang merupakan suatu masalah yang dapat mengakibatkan penurunan produktivitas lahan. Ketidakpahaman terhadap permasalahan erosi, mengakibatkan petani merasa enggan untuk belajar melakukan percobaan konservasi seperti yang disarankan para peneliti yang terlibat pada kegiatan penelitian konservasi tanah dan air. Banyak petani anggota kelompok juga tidak serta merta bersedia mengadopsi teknologi konservasi tanah dan air yang dianjurkan karena dampaknya pada produktivitas lahan tidak langsung dapat dirasakan oleh petani.

Kelompok tani hutan pada dasarnya merupakan syarat bagi berlangsungnya pembelajaran sosial. Kelompok tani yang lemah akan menghambat keinginan petani untuk berupaya mendapatkan pemahaman mengenai suatu fenomena seperti erosi dan pentingnya melakukan konservasi. Rendahnya pemahaman petani akan mencegah petani untuk melakukan adopsi teknik konservasi tanah dan air.

3. Tindakan bersama (Collective action)

Kegiatan konservasi dapat berjalan efektif ketika tindakan bersama tumbuh dalam kehidupan masyarakat petani. Tindakan bersama berjalan ketika petani melakukan upaya bersama dalam suatu kelompok berdasarkan kepada kepentingan dan harapan bersama yang muncul. Tindakan bersama diperlukan agar petani mampu membangun aturan dalam pengelolaan sumber daya alam, mengkoordinasikan kegiatan, memonitor ketaatan atau kepatuhan pada aturan yang berlaku dan menjalankan sanksi bagi pelanggarnya, serta memobilisasi atau mengerahkan sumber daya, tenaga maupun dana (Knox \& Meinzen-Dick, 1999).

Knox dan Meinzen-Dick (1999) lebih lanjut menjelaskan bahwa group (kelompok tani hutan) seharusnya bisa mendorong terjadinya tindakan bersama untuk memengaruhi pilihanpilihan petani pada teknologi yang lebih efisien dan bisa digunakan untuk menjaga kelestarian lingkungan. Bagi kelompok-kelompok tani 
hutan marginal, tindakan bersama bisa dimanfaatkan untuk mendorong adopsi inovasi suatu teknologi dan mengembangkannya serta memodifikasi sesuai dengan kepentingan dan kemampuan kelompok dalam menerapkan teknologi tersebut.

Tindakan bersama hanya mungkin terjadi jika didukung oleh organisasi yang matang. Tidak adanya organisasi atau institusi yang menghimpun terjadinya tindakan bersama akan menghambat keberhasilan upaya mendorong proses adopsi koservasi. Dengan demikian dapat dipahami bahwa kegagalan upaya melakukan difusi inovasi konservasi pada kelompok tani hutan Dadi Rejo dan Wonosasri I, juga disebabkan karena institusi kelompok tani hutan belum mampu mendorong berlangsungnya gerakan konservasi pada anggota kelompok. Kegagalan kelompok tani hutan tersebut salah satu penyebabnya adalah minimnya penguatan dan pendampingan dari peneliti.

Tidak adanya tindakan bersama untuk konservasi mengakibatkan komitmen anggota menjadi sangat rendah. Anggota kelompok tani hutan Dadi Rejo dan Wonosari I tidak bersedia dengan suka rela meniru teknologi konservasi dengan teras bangku yang miring ke dalam dan menanam pohon pada lahan garapannya. Alasan utama penolakan adalah mahalnya biaya pembuatan dan pemeliharaan teras bangku yang miring ke dalam, meskipun peneliti telah mengajukan alternatif agar pembuatan teras dilakukan secara bertahap atau yang biasa disebut 'teras kredit' agar lebih murah. Kurangnya pemahaman juga mengakibatkan petani cenderung menganggap penerasan lahan akan mengurangi luas bidang olah, sedangkan tanaman buah maupun kayu pada sistem agroforestri menyebabkan penurunan produksi, karena akar tanaman serta daun yang menaungi akan mengganggu pertumbuhan tanaman pokok.

Dengan tidak adanya tindakan bersama, aturan atau kaidah dan norma (rules dan norms) konservasi tidak dapat dipaksakan untuk tumbuh dalam kehidupan masyarakat petani. Tidak adanya aturan atau kaidah menyebabkan tidak adanya sanksi bagi yang tidak bersedia menerapkan konservasi. Longgarnya situasi ini menyebabkan disinsentif bagi pengembangan kegiatan konservasi di kedua kelompok tani hutan yang menjadi subyek penelitian.

4. Adaptasi

Sangat disadari bahwa penerapan konservasi akan merubah banyak hal, khususnya pada pola kehidupan petani, seperti cara bercocok tanam, biaya (input) yang harus dikeluarkan, dan yang paling penting adalah produksi (output) dari usaha tani dan kehutanan tersebut. Perubahan biaya dan produksi usaha tani tentu saja sangat memengaruhi kehidupan rumah tangga petani, karena konservasi tanah dan air kemungkinan akan berdampak pada penurunan produksi terutama pada tahun-tahun awal. Oleh karena itu, perlu dilakukan upaya-upaya adaptasi pada situasi tersebut.

Keberhasilan proses adaptasi menurut Agrawal dan Perrin (2008) sangat tergantung pada perencanaan kelembagaan. Agrawal dan Perrin (2008) menekankan bahwa adaptasi tidak akan berjalan pada masyarakat yang tidak memiliki institusi yang bisa mengorganisir anggotanya untuk menyiapkan strategi menghadapi resiko yang mungkin muncul. Pada proses adaptasi institusi diperlukan untuk serangkaian hal, seperti mengorganisir bantuan atau insentif untuk meringankan beban petani. Institusi juga diharapkan keberadaannya untuk bisa memobilisasi aset-aset yang dimiliki anggota untuk mengurangi penderitaan akibat resiko dari teknik konservasi yang diterapkan, terutama bagi petani miskin. Institusi dipercaya mampu menjembatani proses mediasi antara petani dan peneliti atau penyuluh sehingga teknologi konservasi tanah dan air yang harus diterapkan dapat dimodifikasi sesuai kemampuan petani.

Jika kelompok tani hutan Dadi Rejo dan Wonosari I dapat mengkoordinasikan anggota untuk menyiapkan strategi mengurangi resiko akibat penerapan teknologi konservasi, maka anggota tidak perlu merasa khawatir bahwa konservasi akan mengguncang stabilitas ekonomi rumah tangga. Namun demikian, karena kelompok tani hutan tersebut belum mampu menghimpun anggota untuk bekerja dan bersama-sama menanggung biaya (cost and risk sharing) yang dikeluarkan untuk membangun bangunan konservasi serta menanggung kerugian akibat penerapan teknologi konservasi 
tanah dan air, maka petani merasa berat menanggung beban kerugian sendiri. Oleh karena itu, sangat bisa dimengerti bahwa absensi kelompok tani hutan berakibat pada penolakan petani untuk menerapkan konservasi, dengan pertimbangan bahwa mereka tidak memiliki kemampuan untuk beradaptasi pada situasi sulit yang kemungkinan muncul akibat penerapan teknologi konservasi tanah dan air tersebut.

5. Pemanfaatan modal sosial (social capital) secara efisien

Telah banyak penelitian menyatakan bahwa tingkat adopsi teknologi konservasi tanah dan air akan meningkat saat suatu bentuk yang tepat dari modal sosial seperti kerjasama, kohesi sosial, dan jejaring kerja dikembangkan (Cramb, 2004). Modal sosial didefinisikan sebagai suatu bentuk organisasi sosial yang memfasilitasi berlangsungnya kerjasama dan koordinasi untuk keuntungan anggota dan masyarakat secara keseluruhan (Putnam, 1995).

Ketika konservasi tanah dan air diharapkan diterapkan pada lahan suatu kelompok masyarakat, maka diperlukan suatu bentuk koordinasi untuk mengembangkan dan memanfaatkan modal sosial yang dimiliki petani anggota. Hal ini penting agar gerakan ini sukses diterapkan karena konservasi tanah dan air bagi petani hanya bersifat sukarela. Namun, ketika kelompok tani hutan belum mampu mengembangkan modal sosial, seperti kerjasama dan kohesi sosial di antara petani, maka setiap anggota harus menghadapi kesulitannya sendiri tanpa bantuan kelompoknya. Kondisi ini berakibat pada penolakan untuk menerapkan teknologi konservasi tanah dan air. Kerjasama dapat dimanfaatkan untuk mengurangi biaya yang muncul dalam penerapan teknologi konservasi tanah dan air tersebut seperti pembuatan teras yang dilakukan dengan gotong royong secara bergantian pada lahan anggota kelompok. Kuatnya ikatan sosial pada masyarakat desa juga dapat dimanfaatkan untuk memecahkan masalah yang dihadapi bersama. Ikatan yang kuat juga penting untuk mengembangkan nilai dan norma konservasi tanah dan air bersama, serta menjaga agar setiap anggota taat atau patuh terhadap komitmen yang dibuat untuk bersamasama menerapkan teknologi konservasi tanah dan air.
Petani kecil seperti anggota kelompok tani hutan Dadi Rejo dan Wonosari I menyatakan mengalami kesulitan menghadapi kendala yang muncul saat penerapan teknologi konservasi tanah dan air, dan mengharapkan mendapatkan bantuan untuk meringankan beban ekonomi. Jika kelompok tani hutan Dadi Rejo dan Wonosari I memiliki jejaring kerja yang luas, maka mereka bisa mencari dukungan dari berbagai lembaga untuk meringankan beban petani. Kelompok tani hutan Dadi Rejo dan Wonosari I belum mampu mengembangkan jejaring kerja sehingga mengakibatkan kemungkinan membangun kemitraan dengan lembaga-lembaga lain baik itu pemerintah maupun pengusaha untuk meringankan beban petani masih sulit dilakukan.

\section{Peran Pemerintah Daerah}

Konservasi tanah dan air merupakan suatu sistem pengetahuan yang sangat kompleks untuk dipelajari dan diterapkan terutama bagi petani kecil. Oleh karena itu, agar penerapannya bisa berdampak luas membutuhkan dukungan kebijakan pemerintah (Friedrich et al., 2009). Pemerintah daerah dalam hal ini dinas kehutanan baik di kabupaten Wonogiri maupun kabupaten Temanggung telah membuat berbagai macam kegiatan dan proyek konservasi tanah dan air, namun sejauh ini hasilnya belum memberikan hasil sesuai dengan yang diharapkan.

Tingginya tingkat kegagalan proyek-proyek konservasi tanah dan air, salah satunya disebabkan masa proyek yang pendek dan pada umumnya hanya dirancang selama satu tahun. Pendeknya waktu pelaksanaan proyek ini membawa konsekuensi bahwa setiap proyek yang dirancang pemerintah daerah tidak terpelihara secara lestari, karena akan segera diabaikan oleh petani manakala proyek berhenti. Kelompok tani hutan Dadi Rejo dan Wonosari I merupakan contoh kelompok tani hutan yang belum dapat dilepas untuk mengembangkan aktivitasnya secara mandiri, dan masih banyak kelompok tani hutan lain yang serupa.

Sulitnya perluasan adopsi teknologi konservasi tanah dan air juga disebabkan karena konservasi hanya bersifat sukarela (voluntary) pada kedua lokasi penelitian. Kesulitan menjadikan konservasi tanah dan air sebagai suatu peraturan yang mengikat 
(mandatory) adalah karena pemerintah (daerah) tidak dapat memberikan penjelasan terukur tentang manfaat yang bisa diperoleh petani dengan menerapkan teknologi konservasi tanah dan air tersebut, serta kapan manfaat ini bisa dirasakan petani. Studi yang dilakukan Bank Dunia menekankan pentingnya menyampaikan manfaat ekonomi konservasi tanah dan air agar petani bersedia melakukan adopsi (Bergsma, 2000). Oleh karena itu Bergsma (2000) menyarankan penting bagi pemerintah untuk memberikan informasi mengenai analisis ekonomi yang lebih luas, karena petani masih harus menghadapi berbagai kendala lain seperti ketidakpastian pasar.

Tingginya biaya yang harus dikeluarkan untuk menerapkan teknologi konservasi tanah dan air serta rendahnya keuntungan ekonomi yang ditawarkan, menjadi alasan bagi sebagian besar petani, termasuk petani subyek penelitian, untuk menolak mengadopsi teknologi konservasi tanah dan air, kecuali ada insentif yang diberikan (Vanclay, 1994). Namun demikian, keterbatasan kemampuan keuangan daerah mengakibatkan insentif tidak selalu bisa diberikan kepada petani. Hal ini juga terkait dengan rendahnya kinerja dan kreativitas pemerintah (daerah) dalam merancang program dan kegiatan yang bisa mendorong perluasan adopsi teknologi konservasi tanah dan air. Petani pada umumnya mengharapkan subsidi diberikan dalam bentuk uang. Tidak demikian halnya dengan yang terjadi di kelompok tani hutan Dadi Rejo dan Wonosari I. Anggota kelompok tani hutan Dadi Rajo dan Wonosari I memberikan beberapa alternatif bantuan yang diinginkan antara lain dapat berupa, (1) informasi pasar. Banyak petani menghadapi kendala pemasaran produknya, terutama ketika petani dianjurkan untuk mengubah komoditas tanaman yang diusahakannya dengan tanaman yang memiliki fungsi konservasi. Jika pemerintah dapat menjamin pemasaran produksi usaha tani hutan yang baru, petani responden menyatakan bersedia mengganti dengan tanaman baru tersebut; (2) kemudahan mendapatkan pupuk bersubsidi. Pupuk terutama bagi anggota kelompok tani hutan Dadi Rejo merupakan masalah yang sulit diatasi. Tidak hanya karena harganya yang mahal namun juga karena seringkali sulit mendapatkannya dipasaran. Kemudahan akses terhadap pupuk bersubsidi menjadi insentif tersendiri bagi petani. Dengan demikian, mereka bisa mengalokasikan aset yang dimiliki untuk kegiatan-kegiatan konservasi lahan; (3) salah satu yang menjadi kendala pemasaran hasil pertanian atau kehutanan adalah tidak tersedianya infrastruktur yang baik seperti jalan dan sarana transportasi. Akibatnya harga jual produk pertanian atau kehutanan di tingkat petani pada lokasi penelitian terutama di desa Pulutan Wetan menjadi rendah. Tidak adanya transportasi desa menyebabkan penjual sulit menjual secara langsung namun harus menunggu pembeli datang. Kondisi ini mengakibatkan petani tidak memiliki posisi tawar yang baik, dan hanya mendapatkan keuntungan yang sedikit. Rendahnya keuntungan akan berdampak pada rendahnya perhatian terhadap kegiatan konservasi lahan. Oleh karena itu sangat penting diutamakan agar pemerintah memberikan perhatian pada perbaikan infrastruktur desa; (4) akses terhadap air. Air merupakan masalah yang menghambat ekstensifikasi dan diversifikasi dalam pengelolaan lahan dikedua lokasi penelitian. Akibatnya petani tidak memiliki banyak alternatif pilihan tanaman yang ditanamnya. Kondisi ini juga mencegah mereka menanam tanaman konservasi yang disarankan seperti tanaman buah dan tanaman kayu, karena ingin mengoptimalkan lahan untuk pertanian saat musim hujan. Tanaman buah dan kayu hanya akan mengurangi luas bidang olah dan menyebabkan penurunan produksi. Demikian juga dengan teras yang dipandang akan mengurangi luas bidang olah. Namun banyak petani responden berpendapat jika akses terhadap air terutama saat musim kemarau tersedia, petani bersedia menanam tanaman konservasi karena musim kemarau mereka tetap bisa mengusahakan lahannya untuk pertanian sehingga stabilitas ekonomi terjaga.

Insentif dari pemerintah bagi petani yang bersedia menerapkan konservasi sangat penting. Menurut Vanclay (1994), hal ini karena beban yang harus disandang akibat penerapan konservasi diletakkan pada petani secara individual. Sedangkan manfaat dari konservasi bersifat sosial, karena dapat dirasakan bahkan oleh masyarakat yang tinggal jauh di hilir suatu daerah aliran sungai.

Selain berbagai program insentif, pemerintah daerah juga harus memikirkan disinsentif yang akan diberikan kepada pengelola lahan yang tidak bersedia menerapkan konservasi. Responden mengemukakan disinsentif yang mungkin bisa mendorong petani melakukan konservasi tanah dan air, antara lain adalah; (1) tidak mendapatkan akses terhadap kredit. Pemerintah daerah sering 
kali merancang berbagai program kredit bagi masyarakat tani hutan. Jika program ini hanya diberikan kepada mereka yang mengkonservasi lahannya, baik dengan teras maupun tanaman kayu, maka petani lain dipastikan akan meniru melakukan konservasi yang sama mekipun dengan motivasi untuk mendapatkan kredit; (2) tidak menjadi prioritas untuk mendapatkan berbagai subsidi. Pemerintah daerah juga perlu memperhatikan memberi prioritas dan kemudahan berbagai subsidi kepada mereka yang secara sadar menerapkan praktek konservasi tanah dan air. Responden menyatakan saat disinsentif seperti tidak mendapatkan subsidi beras untuk masyarakat miskin, pupuk, bibit dan sebagainya diberikan kepada mereka, sementara pelaku konservasi mendapat berbagai kemudahan maka responden menyatakan bersedia menerapkan konservasi.

Oleh karena itu perlu diterapkan secara bijaksana insentif dan disinsentif yang harus diberikan oleh pemerintah agar praktek konservasi tanah dan air benar-benar diterapkan masyarakat. Program insentif dan disinsentif tersebut akan bermakna dan berdampak jika dituangkan dalam kebijakan pemerintah.

\section{Peran Penyuluh}

Semakin kompleknya permasalahan yang dihadapi masyarakat tani hutan membuat kehadiran penyuluh menjadi sangat diperlukan. Tujuan utama dibentuknya penyuluh sangat berkaitan dengan kegiatan transfer teknologi, pengetahuan dan kemampuan di bidang pengelolaan lahan (Swanson, 2008). Namun dari berbagai penghargaan yang diberikan kepada penyuluh karena keberhasilan mereka mendukung revolusi hijau, keprihatinan muncul karena pengelolaan lahan terutama untuk kegiatan pertanian tidak lagi mengindahkan kaidah konservasi.

Tantangan program-program penyuluhan menjadi semakin besar, terutama ketika penyuluh harus menyadari peran dan fungsinya yang berbeda ketika melakukan penyuluhan (polivalen). Oleh karena itu penyuluh perlu diberi keterampilan yang luas, karena melakukan penyuluhan yang bertujuan untuk meningkatkan produksi pertanian sangat berbeda dengan penyuluhan yang bertujuan untuk mendorong masyarakat melakukan konservasi (Vanclay, 1994). Begitu pentingnya peran penyuluh, beberapa study (Kalineza et al, 1999; Vanclay, 1994) menyimpulkan bahwa kehadiran penyuluh mampu memengaruhi terjadinya adopsi teknologi kenservasi. Sayangnya pada kedua lokasi penelitian, penyuluh jarang berkunjung pada kelompok tani hutan. Hal ini disebabkan karena luasnya daerah binaan penyuluh sedangkan kedua lokasi penelitian sangat jauh dari pusat pemerintahan. Rendahnya anggaran penyuluhan juga menjadi faktor penghambat tidak semua lokasi binaan penyuluh dapat terjangkau. Responden penelitian menyatakan sangat mengharapkan kehadiran penyuluh, karena penyuluh sangat diharapkan peranannya dalam beberapa hal berikut.

(1) Mengajar dan memotivasi petani. Responden menyatakan seringkali bereksperimen dengan beberapa tanaman baru terutama tanaman kehutanan dan tanaman buah. Diakui bahwa ketidakhadiran penyuluh sebagai pendamping sering menjadi penghambat karena banyak pertanyaan dan kekhawatiran muncul yang tidak bisa dijawab terutama mengenai manfaat tanaman tersebut secara ekonomi. Pada kondisi ini diharapkan penyuluh mampu berperan mendorong petani melakukan percobaan pada skala kecil. Dengan demikian bisa mengurangi resiko kegagalan serta memberi kesempatan kepada petani untuk mengembangkannya dan menyesuaikan dengan kemampuan masingmasing.

(2) Memberi arahan teknologi yang paling tepat diterapkan. Penyuluh diharapkan memahami komunitas masyarakat yang dibinanya berikut keadaan lingkungan yang ada. Dengan demikian diharapkan bisa membantu memberi informasi yang akurat mengenai pilihan teknologi konservasi yang paling tepat diterapkan pada wilayah binaannya.

(3) Mendorong para pemimpin desa untuk mulai secara mandiri mencari dan mengembangkan pengetahuan mengenai kegiatan pengelolaan lahan yang sesuai kaidah konservasi serta melakukan transfer teknologi kepada masyarakatnya. Jika penyuluh mampu melakukan hal ini, maka pendekatan baru pada bidang penyuluhan pedesaan yang dianggap efektif mendukung program-program pemerintah terutama konservasi yaitu farmer-led extension akan cepat terlaksana. Dorongan penyuluh kepada para pemimpin desa sangat penting pada kedua lokasi penelitian, karena masyarakat disini masih sangat patuh kepada 
pemimpinnya. Kondisi seperti ini akan memberikan keuntungan bagi keberhasilan kegiatan konservasi.

Demikian pentingnya peran penyuluh, maka ketidakhadirannya akan mengurangi kemampuan masyarakat baik secara individual maupun berkelompok untuk menghadapi tekanan atau stres, kesulitan, serta pada akhirnya tidak mampu beradaptasi dengan perubahan (Hunt, 2011). Penyuluh merupakan garda terdepan dari upaya transfer teknologi konservasi, penyuluh diharapkan memiliki kemampuan keorganisasian, pemahaman kondisi geografi setempat, pengetahuan mengenai bisnis sehari-hari dari masyarakat desa, serta selalu siap jika ada program pembangunan yang harus dilaksanakan dengan segera. Dengan demikian pada kelompok masyarakat yang didampingi penyuluh, aliran informasi akan berjalan efektif dan program-program pembangunan termasuk konservasi akan berjalan dengan lebih baik.

\section{KESIMPULAN DAN SARAN}

\section{A. Kesimpulan}

Institusi memegang peranan penting dalam proses perluasan adopsi teknik konservasi, sehingga keberadaan institusi menentukan diadopsinya suatu teknologi. Institusi terbukti sangat produktif untuk digunakan sebagai sarana diseminasi teknologi. Pada masyarakat yang memiliki disfungsi institusi proses adopsi teknik konservasi tanah dan air menjadi terkendala. Hal ini karena institusi yang ada tidak bisa menjadi sumber informasi mengenai pentingnya melakukan konservasi tanah dan air pada lahan pertaniannya, serta tidak mampu memberikan perlindungan kepada petani pada saat petani mengalami kesulitan akibat penerapan teknik konservasi tersebut. Disfungsi institusi juga mengakibatkan petani tidak bisa memanfaatkan secara efisien sumber daya yang dimilikinya baik secara individu maupun berkelompok seperti pengetahuan, ketrampilan, jejaring kerja, infrastruktur, sifat kegotongroyongan masyarakat, dan sebagainya.

\section{B. Saran}

1. Perlu dipikirkan berbagai upaya untuk meningkatkan kemampuan lembaga-lembaga masyarakat yang ada agar kegiatan konservasi mendapat dukungan penuh dari masyarakat desa.

2. Pemerintah juga perlu membuat kebijakan mengenai insentif yang akan diberikan kepada petani yang dengan sadar menerapkan konservasi pada lahannya. Hal ini ditujukan untuk memberikan kompensasi atas beban hidup dan biaya yang dikeluarkan akibat penerapan teknologi konservasi tanah dan air tersebut. Kebijakan disinsentif juga sebaiknya diberikan kepada mereka yang tidak menerapkan konservasi, untuk memberikan motivasi kepada petani agar meniru pelaku konservasi.

3. Penyuluhan kehutanan harus terus digiatkan, karena ketidakhadiran penyuluh mengakibatkan penurunan norma dan nilai konservasi di masyarakat desa. Penyuluh sebagai garda terdepan dalam perluasan konservasi harus diberi keterampilan yang luas mengenai berbagai hal misalnya informasi pasar mengenai tanaman konservasi yang dikenalkannya.

\section{DAFTAR PUSTAKA}

Agrawal, A \& Gibson, C.C. (1999). Enchantment and disenchantment: the role of community in natural resource conservation. World Development, 27(4), 629-649.

Agrawal, A. \& Perrin, N. (2008). Climate adaptation, local Institutions, and rural livelihoods. IFRI Working Paper \# W08I-6. International Forestry Resources and Institutions Program. http://www.umich.edu/ ifri/. Diakses: 25/03/2013.

Akinnagbe, O.M. \& Ajayi, A.R. (2010). Challenges of farmer-led extension approaches in Nigeria. World Journal of Agricultural Sciences, 6(4), 353-359.

Bergsma, E. (2000). Incentives of land users in projects of soil and water conservation, the weight of intangibles. Geo Journal, 50, 47-54.

Bromley, D. 2008. Resource Degradation in the African commons: accounting for institutional decay. Environment and Development Economics,13, 539-563. 
Cramb, R.A. (2004). Social capital and soil conservation: evidence from the Philippine. Contributed Paper 48th Annual Conference Australian Agricultural \& Resource Economics Society. Melbourne, 10-13 February 2004.

Doss, C.R. (2006). Analyzing technology adoption using micro studies: limitation, challenges, and opportunities for improvement. AgriculturalEconomics, 34, 207-219.

Franzel, S., Cooper, P. \& Denning, G. L. (2001). Scaling up the benefits of agroforestry research: Lessons learned and research challenges. Development in Practice, 11(4), 524534.

Friedrich, T., Kassam, A. \& Taher, F. (2009). Adoption of conservation agriculture and the role of policy and institutional support. Invited paper for the International Consultation on "No-Till with Soil Cover and Crop Rotation: A Basis for Policy Support to Conservation Agriculture for Sustainable Production Intensification". Astana \& Shortandy, Kazakhstan. 8-10 July 2009.

Kalineza, H.M.M., Mdoe, N.S.Y. \& Mlozi, M.R.S. (1999). Factors influencing adoption of soil conservation technologies in Tanzania: a case study in Gairo. Preceedings of Fo A, 4, 76-83

Hunt, W., Vanclay, F., Birch, C., Coutts, J., Flittner, N. \& Williams, B. (2011). Agricultural extension: building capacity and resilience in rural industries and communities. Rural Society, 20(2), 112-127.

Knox, A \& Meinzen- Dick, R. (1999). Property rights, collective action, and technologies for natural resource management. CGiAR Systemwide Program on Collective Action and Property Rights. Policy Brief, Number 1 October 1999.

Lee, D.R. (2005). Agricultural sustainability and technology adoption: issues and policies for developing countries. American Journal of AgriculturalEconomic, 87(5),1325-1334.

Matsaert, H. (2002). Institutional analysis in natural resources research. Socio-economic Methodologies for Natural Resources Research. Best Practice Guidelines.
Chatham, UK: Natural Resources Institute. ISBN 085954 496-6.

McKell, D. \& Peiretti, R.A. (2004). Promoting soil conservation and conservation agriculture through farmer associations. Paperpresented at the ISCO 2004 - 13th International Soil Conservation Organisation Conference. Brisbane, July 2004. Conserving Soil and Water for Society: Sharing Solutions.

Muro, M \& Jeffery, P. (2008). A critical review of the theory and application of social learning in participatory natural resource management processes. Journal of Environmental Planning and Management, 51(3), 325-344.

Nuryanti, S \& Swastika, D.K.S. (2011). Peran kelompok tani dalam penerapan teknologi pertanian. Forum Penelitian Agro Economi, 29(2), 115-128.

Pannell, D.J., Marshall, G.R., Barr, N., Curtis, A., Vanclay, F. \& Wilkinson, R. (2006). Understanding and promoting adoption of conservation practices by rural landholders. Australian Journal of Experimental Agriculture, 46(11), 1407-1424.

Putnam, R. (1995). Bowling alone: America $\square \mathrm{s}$ declining social capital. Journal of Democracy, 6(1), 65-78.

Rist, S., Chidambaranathan, M., Escobar, C. \& Wiesmann, U. (2006). 'It was hard to come to mutual understanding...' the multidimensionality of social learning processes concerned with sustainable natural resources use in India, Africa and Latin America. Systemic Practice and Action Research, 19(3), 219-237.

Robbins, M., \& Williams, T. O. (2005). Land management and its benefits: The challenge, and the rationale, for sustainable management of drylands. A paperpresented at a STAP Workshop on Sustainable Land Management. Washington DC.

Rogers, E. (2003). Diffusion of innovations ( $5^{\text {th }}$ ed.). New York: The Free Press.

Shiferaw, B.A., Okello, J. \& Reddy, R.V. (2009). Adoption and adaptation of natural 
resource management innovations in smallholder agriculture: reflections on key lessons and best practices. Environ Dev Sustain, 11, 601-619.

Swanson, B.E. (2008). Global Review of Good Agricultural Extension and Advisory Service Practices. Research and Extension Division Natural Resources Management and Environment Departmentand Policy
Assistance and Resources Mobilization Division Technical Cooperation Department. Rome: FAO.

Vanclay, F. \& Lawrence, G. (1994). Farmer rationality and the adoptionof environmentally sound practices; A critique of the assumptions of traditional agricultural extension. European Journal of Agricultural Education and Extension, 1(1), 59-90. 


\title{
KARAKTERISTIK MASYARAKAT SUB DAS PENGKOL DALAM KAITANNYA DENGAN PENGELOLAAN DAS \\ (Studi Kasus di Sub DAS Pengkol, Kabupaten Wonogiri, Jawa Tengah) (Characteristics of Society Pengkol Sub-Watershed in Relation with Watershed Management (Case study in Pengkol Sub-Watershed, Wonogiri Regency, Central Java))
}

\author{
Nur Ainun Jariyah ${ }^{1}$ \\ ${ }^{1}$ Balai Penelitian Teknologi Kehutanan Pengelolaan Daerah Aliran Sungai. \\ Jl. A. Yani PO Box 295 Pabelan. Telepon/Fax.: (+62 271) 716709/716959 \\ E-mail: nurainun_2513@yahoo.co.id \\ Diterima 8 Juli 2013, direvisi 3 Februari 2014, disetujui 21 Februari 2014
}

\begin{abstract}
Pengkol Sub-watershed is part of the Keduang watershed, where is one of the sub-watersheds that contribute to erosion and sedimentation in the Gadjah Mungkur reservoir. Base on the problems that exist in the upstream, the aims of study to investigate the characteristics of upstream social culture of the community in relation to watershed management. The research was conducted in the Pengkol sub-watershed in Wonogiri district, represented by the area upstream, midstream and downstream. This activity is a qualitative research. Data taken include primary data and secondary data. The parameters are taken the identity of respondents, population density, culture, land and institutional dependency. Data is collected by conducting interviews with questionnaire and indepth interviews with key person. Random selection of respondents drawn proportionately adjusted for the purpose of research. Data analysis was done by descriptive qualitative. The conclusion of this study were (1) Characteristics of upstream communities are generally farmers with age is still productive. Farmers are aware of the benefits and impacts of not implement soil conservation, (2) In general, farmers have more than one of field land and planted crops intercropping, medicinal spices and woody plants, (3) family income the three villages is above in Living Needs, (4) Need for better coaching and structured to build communities upstream with community, (5) It needs a reward for people who havepracticed soil conservation activities in upstream.
\end{abstract}

Keywords: Characters of farmers, watershed management, Pengkol Sub-watershed, conservation

ABSTRAK

Sub DAS Pengkol merupakan bagian dari DAS Keduang, yang merupakan salah satu sub DAS penyumbang erosi dan sedimentasi di Waduk Gadjah Mungkur. Berdasarkan permasalahan-permasalahan yang ada di daerah hulu, maka kajian ini bertujuan untuk mengetahui karakteristik sosial budaya masyarakat hulu dalam kaitannya dengan pengelolaan DAS. Penelitian ini dilakukan di wilayah Sub DAS Pengkol di Kabupaten Wonogiri, diwakili oleh wilayah hulu, tengah dan hilir. Data yang diambil meliputi data primer dan data sekunder dengan parameter identitas responden, kepadatan penduduk, budaya, ketergantungan lahan dan kelembagaan. Pengambilan data menggunakan teknik wawancara dengan panduan kuesioner dan wawancara mendalam kepada tokoh kunci. Pemilihan responden dilakukan secara acak proporsional sesuai tujuan penelitian, dan analisis data menggunakan metode deskriptif kualitatif. Hasil penelitian menunjukkan bahwa (1) Karakteristik masyarakat hulu pada umumnya adalah petani dengan umur masih produktif. Petani sudah paham akan manfaat dan dampak konservasi tanah apabila tidak dilakukan, (2) Pada umumnya petani mempunyai lahan lebih dari satu bidang dan ditanami tanaman tumpangsari, empon-empon dan tanaman berkayu, (3) Pendapatan keluarga ketiga desa lebih besar dari Kebutuhan Hidup Layak, (4) Perlu adanya pembinaan yang lebih baik dan terstruktur untuk membangun daerah hulu bersama masyarakat, (5) Perlu adanya reward untuk masyarakat hulu yang telah melakukan kegiatan konservasi tanah.

Kata kunci: Karakter petani, managemen DAS, Sub DAS Pengkol, konservasi 


\section{PENDAHULUAN}

Sub DAS Pengkol merupakan bagian dari DAS Keduang, yang merupakan salah satu sub DAS penyumbang terbesar erosi dan sedimentasi di Waduk Gadjah Mungkur. Sedimentasi menyebabkan pendangkalan di Waduk Gadjah Mungkur, dimana waduk tersebut berfungsi sebagai penampung air dari hulu, dan pengendali banjir Sungai Bengawan Solo. Perkembangan terakhir diperkirakan umur pakai Waduk Gadjah Mungkur tinggal 10-15 tahun lagi, menurut perencanaan umur pakainya adalah 100 tahun (http://epriant. blogspot.com). Pendangkalan tersebut dikhawatirkan tidak akan mampu menampung air di Sungai Bengawan Solo.

Erosi dan sedimentasi tersebut dimungkinkan karena adanya perubahan fungsi lahan sehingga dapat mengganggu kehidupan masyarakat. Ada tiga hal utama yang dapat menyebabkan Daerah Aliran Sungai di Indonesia terdegradasi. Penyebab utama adalah akibat aktifitas manusia yang meliputi penebangan hutan yang dilakukan secara illegal, kebakaran hutan, perambahan hutan, eksploitasi hutan dan lahan yang berlebihan dan pemanfaatan lahan yang tidak menerapkan konservasi tanah dan air (http:/ / www.scbfwm.org).

Sheng (1986) dalam Paimin dkk (2006) menyatakan bahwa permasalahan DAS tumbuh seiring dengan pertambahan penduduk dan waktu. DAS sangat dipengaruhi oleh bagian hulu, kondisi biofisik daerah tangkapan dan daerah resapan air. Pada umumnya kondisi di daerah hulu rawan terhadap gangguan manusia (www.bappenas.go.id). Menurut Atmojo (2009) pengelolaan DAS bagian hulu sering menjadi fokus perhatian, mengingat kawasan DAS bagian hulu dan hilir mempunyai keterkaitan biofisik melalui daur hidrologi, sehingga kesalahan penggunaan lahan daerah hulu akan berdampak pada masyarakat di daerah hilir.

Pola usaha tani hulu DAS sebagian besar dilakukan oleh petani lahan kering yang tidak terlepas dari keterbatasan kondisi sosial ekonomi, sumber daya, dan kemampuan/keterampilan, sehingga tidak mampu melakukan pengolahan lahan sesuai daya dukung lahan, serta tidak menerapkan teknik konservasi tanah dan air dengan baik (http://www.scbfwm.org). Melihat hal tersebut jelas bahwa kondisi sosial ekonomi masyarakat khususnya daerah hulu sangat berpengaruh terhadap kondisi DAS. Semakin intensif pengelolaan lahan daerah hulu akan mempengaruhi kondisi daerah hilir. Kajian ini bertujuan untuk mengetahui karakteristik sosial budaya masyarakat hulu dalam kaitannya dengan pengelolaan DAS. Diharapkan dari kajian ini dapat memberikan bahan masukan pemegang kebijakan untuk mengatur daerah hulu.

\section{METODE PENELITIAN}

\section{A. Lokasi Penelitian}

Penelitian ini dilakukan di wilayah Sub DAS Pengkol di Kabupaten Wonogiri. Untuk memperoleh gambaran yang jelas dalam menjawab tujuan, setiap lokasi penelitian dibedakan menjadi hulu, tengah dan hilir. Lokasi penelitian tersebut dilakukan di Desa Setren, Kecamatan Slogohimo mewakili hulu, wilayah tengah diwakili oleh Desa Karang, Kecamatan Slogohimo dan wilayah hilir diwakili oleh Desa Sugihan, Kecamatan Jatiroto.

Sub DAS Pengkol mempunyai luas 3.057,59 ha, dan merupakan bagian dari Sub DAS Keduang. Lokasi penelitian sub DAS Pengkol dapat dilihat pada Gambar 1.

\section{B. Pengumpulan Data}

Data penelitian meliputi data primer dan data sekunder. Sebagai parameter penelitian adalah identitas responden, kepadatan penduduk, budaya, ketergantungan terhadap lahan dan kelembagaan.

Pengambilan data dilakukan menggunakan metode wawancara dengan panduan kuesioner dan wawancara mendalam kepada tokoh kunci. Responden penelitian adalah petani pemilik lahan tegal, dipilih secara acak proporsional sesuai tujuan penelitian, yaitu sebanyak 30 orang di masing-masing wilayah hulu, tengah dan hilir, sehingga jumlah responden adalah 90 orang. Pengumpulan data sekunder dilakukan di instansi terkait seperti Balai Sungai, Kementrian Pekerjaan Umum, Dinas Pertanian, Dinas Kehutanan, Kesbanglinmas, dan BPS.

\section{Analisis Data}

Analisis data dilakukan menggunakan metode deskriptif kualitatif. Deskriptif kualitatif adalah mengolah dan menganalisis data-data yang terkumpul menjadi data yang sistematik, teratur, terstruktur dan mempunyai makna (Sarwono, 2006). 


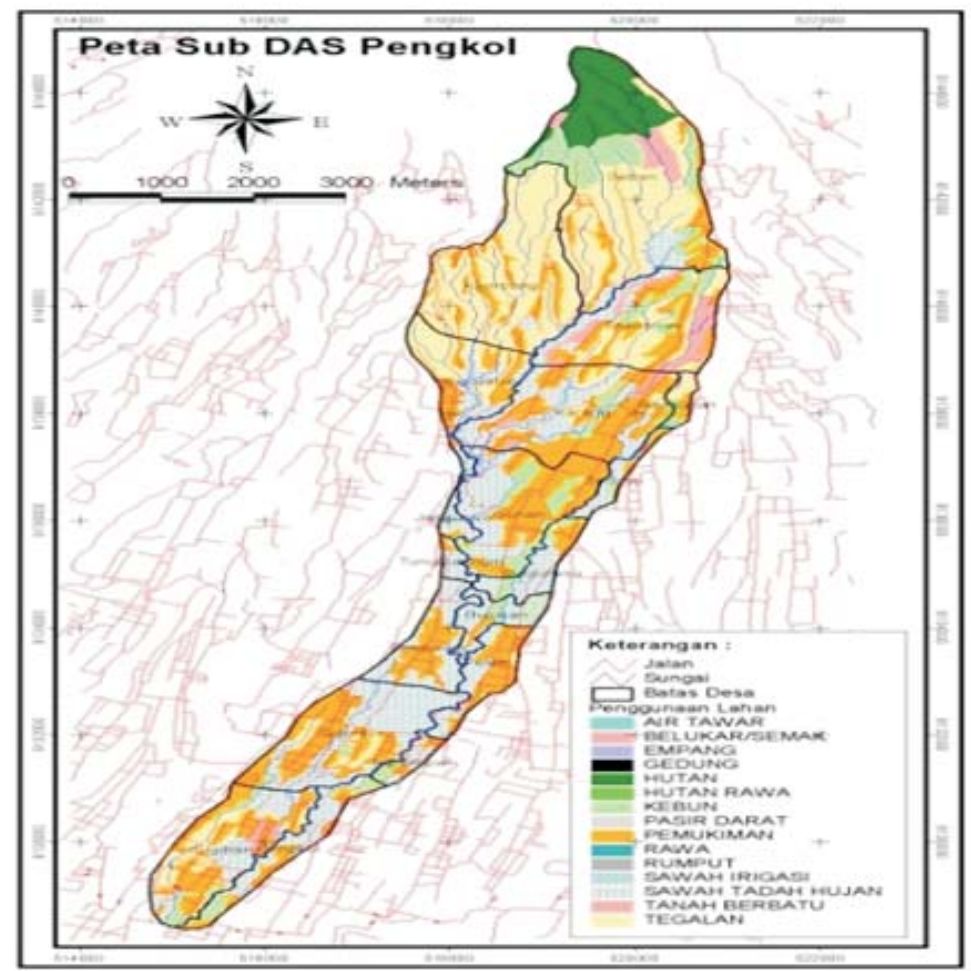

Gambar 1. Lokasi Penelitian di Sub Das Pengkol

Figure 1. Research Sites in Sub-Watershed Pengkol

\section{HASIL DAN PEMBAHASAN}

\section{A. Gambaran Umum Wilayah Penelitian}

Sub DAS Pengkol terletak pada garis lintang $7^{0} 32^{\prime}-8^{0} 15^{\prime}$ LS dan garis bujur $110^{\circ} 41^{\prime}-111^{\circ} 18^{\prime}$ BT dengan luas 3.057,59 Ha. Sub DAS Pengkol secara administratif masuk di Kabupaten Wonogiri. Kabupaten Wonogiri terbagi menjadi 25 kecamatan dengan luas wilayah 182.236,0236 Ha. Keadaan alamnya sebagian besar terdiri dari pegunungan yang berbatu gamping, terutama di bagian selatan, termasuk jajaran Pegunungan Seribu yang merupakan sumber mata air bagi Sungai Bengawan Solo.

Berdasarkan data tahun 2006-2010 jumlah penduduk Kabupaten Wonogiri rata-rata berjumlah 1.200.500 jiwa terdiri laki-laki 602.314 jiwa dan perempuan 598.186 jiwa dengan kepadatan penduduk adalah 659,76 jiwa $/ \mathrm{km}^{2}$, pertumbuhan penduduk sebesar 2,67\%. PDRB tahun 2001-2010 berdasarkan harga berlaku adalah Rp 3.490.426,14 juta didominasi oleh sektor pertanian $51 \%$, jasa $13 \%$, perdagangan, hotel dan resto $12 \%$. PDRB berdasarkan harga konstan adalah Rp. 1.901.402 juta.
Berdasarkan data tahun 2008 rata-rata produksi sawah mengalami kenaikan dari 53,90 kw/ha menjadi 56,09 $\mathrm{kw} / \mathrm{ha}$ dan padi gogo dari 31,20 $\mathrm{kw} / \mathrm{ha}$ menjadi $32,89 \mathrm{kw} / \mathrm{ha}$. Untuk palawija rata-rata produksi masing-masing komoditi mengalami penurunan. Ketersediaan pangan untuk padi dan jagung surplus masing-masing sebesar 58.484 ton padi dan 232.985 ton jagung.

Kondisi penutupan lahan sub DAS Pengkol didominasi oleh sawah $29,30 \%$, tegal $27,80 \%$ dan pemukiman $25,86 \%$. Secara lebih jelas dapat dilihat pada Tabel 1.

Contoh kasus di Desa Kembang, Kecamatan Jatipurno, menurut petani pada saat musim hujan, tanah selalu mengalami erosi yang tinggi, sehingga banyak sedimen yang terlarut dalam sungai dan bermuara di Sub DAS Keduang. Desa Kembang merupakan salah satu penyumbang sedimen terbesar di Sub DAS Keduang. Oleh karena itu, desa tersebut dijadikan proyek penghijauan oleh PT Bakti Usaha Menanam Nusantara Hijau Lestari II (PT BUMN HL II). PT BUMN HL II tersebut merupakan anak perusahaan BUMN di bidang agroindustri yang dimodali secara konsorsium oleh PT Perkebunan Nusantara (PTPN) IX, PTPN X, 
PTPN XI, PTPN XII, Perum Perhutani, PT Petrokimia Gresik, PT Rajawali Indonesia, dan Perum Jasa Tirta I. Perusahaan patungan tersebut bergerak dalam agrobisnis dan agroindustri berbasis pelestarian lingkungan.

Kondisi lahan dengan kelerengan yang curam menyebabkan tanah mudah tererosi, sehingga proyek penghijauan ini diharapkan dapat menanggulangi erosi yang tinggi di Desa Kembang. Jenis tanaman penghijauan ini adalah tanaman karet, sengon salomon dan jabon. Sementara itu tanaman dibawah tegakannya adalah kunyit, serai wangi dan tanaman palawija. Petani diberi kebebasan memilih jenis tanaman keras maupun tanaman di bawah tegakan yang akan ditanam. Pupuk, HOK dan bibit berasal dari PT BUMN HL II, dengan sharing 60\% untuk petani dan $40 \%$ untuk PT BUMN HL II. Selain Desa Kembang, desa lain yang menjadi sasaran adalah Desa Girimulyo dan Desa Balepanjang, Kecamatan Jatipurno.

Tabel 1. Penutupan Lahan di Sub DAS Pengkol

Table 1. Land Cover in Pengkol Sub-Watershed

\begin{tabular}{lrr}
\hline \multicolumn{1}{c}{ Penutupan lahan (land cover) } & Luas (broad) Ha & \multicolumn{2}{c}{$\%$} \\
\hline Hutan (forest) & 1441,954 & 4,64 \\
Kebun (garden) & 270,066 & 8,83 \\
Semak (shrubbery) & 108,589 & 3,55 \\
Lapangan (field) & 0,171 & 0,01 \\
Sawah (rice field) & 895,815 & 29,30 \\
Air tawar (freshwater) & 0,353 & 0,01 \\
Tegal (dry fields) & 850,044 & 27,80 \\
Pemukiman (settlement) & 790,634 & 25,86 \\
\hline Jumlah (amount) & 3057,586 & 100,00 \\
\hline
\end{tabular}

Sumber (Source): Analisis data primer 2010 (Primary analysis 2010)

\section{B. Kondisi Sosial Ekonomi dan Budaya}

\section{Karakteristik Responden}

Responden di Sub DAS Pengkol di ketiga desa rata-rata dalam usia produktif yaitu 44 tahun sampai dengan 52 tahun; dengan pekerjaan tetap didominasi pertanian dan pekerjaan sampingan adalah pertanian, perdagangan dan pertukangan; pendidikan rata-rata SD dan SMP, dengan tanggungan keluarga rata-rata empat orang. Responden yang diwawancarai adalah dari masyarakat biasa, pamong desa dan ketua kelompok tani. Setiap responden minimal mempunyai lahan milik tegal. Secara lebih jelas dapat dilihat pada Tabel 2 dan Tabel 3.

Tabel 2. Karakteristik Responden di Sub DAS Pengkol (Umur, Pekerjaan Tetap dan Pekerjaan Sampingan) Table 2. Characteristics of Respondents in Pengkol Sub-Watershed (Age, Permanent Jobs and Secondary Job)

\begin{tabular}{|c|c|c|c|c|c|c|c|c|c|c|c|c|c|c|c|}
\hline \multirow{2}{*}{$\begin{array}{l}\text { No } \\
\text { (No) }\end{array}$} & \multirow{2}{*}{$\begin{array}{l}\text { Desa (village) } \\
\text { Kecamatan } \\
\text { (sub district) }\end{array}$} & \multirow{2}{*}{$\begin{array}{l}\text { DAS } \\
\text { Keduang } \\
\text { (watershed } \\
\text { keduang) }\end{array}$} & \multirow{2}{*}{$\begin{array}{l}\text { Umur } \\
\text { Rerata (Th) } \\
\text { (mean age) } \\
\text { (year) }\end{array}$} & \multicolumn{6}{|c|}{ Pekerjaan Tetap (permanent job) } & \multicolumn{6}{|c|}{ Pekerjaan Sampingan (secondary job) } \\
\hline & & & & $\begin{array}{l}\text { Tani } \\
\text { (farmer) }\end{array}$ & $\begin{array}{l}\text { Buruh } \\
\text { (labor) }\end{array}$ & $\begin{array}{l}\text { PNS } \\
\text { (civil } \\
\text { servant) }\end{array}$ & $\begin{array}{l}\text { Dagang } \\
\text { (trade) }\end{array}$ & $\begin{array}{l}\text { Tukang } \\
\text { (handyman)) }\end{array}$ & $\begin{array}{l}\text { Lainnya } \\
\text { (Other) }\end{array}$ & $\begin{array}{l}\text { Tani } \\
\text { (farmer) }\end{array}$ & $\begin{array}{l}\text { Buruh } \\
\text { (labor) }\end{array}$ & $\begin{array}{l}\text { Dagang } \\
\text { (trade) }\end{array}$ & $\begin{array}{l}\text { Swsta } \\
\text { (private } \\
\text { sector) }\end{array}$ & $\begin{array}{l}\text { Tukang } \\
\text { (handyman)) }\end{array}$ & $\begin{array}{l}\text { Lainnya } \\
\text { (Other) }\end{array}$ \\
\hline 1 & & & 44 & & & & & & & & & & & & \\
\hline 2 & Karang, Slogohimo & Tengah & 50 & & $6 \%$ & & & & & & & & & & \\
\hline 3 & & Hilir & & & $0 \%$ & & & & & & $11 \%$ & & & & $22 \%$ \\
\hline
\end{tabular}

Sumber (Source): Analisis Data Primer 2010 (Primary data analysis 2010) 
Tabel 3. Karakteristik Responden (Pendidikan, Tanggungan Keluarga, Status dalam Masyarakat) Table 3. Respondent characteristics (Education, Family Dependents, Status in Society)

\begin{tabular}{|c|c|c|c|c|c|c|c|c|c|c|c|c|c|c|}
\hline \multirow{2}{*}{$\begin{array}{l}\text { No } \\
\text { (No) }\end{array}$} & \multirow{2}{*}{$\begin{array}{l}\text { Desa (village) } \\
\text { Kecamatan } \\
\text { (sub district) }\end{array}$} & \multirow{2}{*}{$\begin{array}{l}\text { DAS } \\
\text { Keduang } \\
\text { (watersbed } \\
\text { keduang) }\end{array}$} & \multicolumn{6}{|c|}{ Pendidikan (education) } & \multirow{2}{*}{$\begin{array}{c}\text { Tanggungan } \\
\text { Keluarga } \\
\text { (org/KK) } \\
\text { (family dependent) }\end{array}$} & \multicolumn{5}{|c|}{ Status dalam masyarakat (status in society) } \\
\hline & & & $\begin{array}{l}\text { TS } \\
(n o \\
\text { school }) \\
\end{array}$ & $\begin{array}{c}\text { SD } \\
\text { (primary } \\
\text { school) } \\
\end{array}$ & $\begin{array}{c}\text { TT SD } \\
\text { (not complete } \\
\text { primary school) }\end{array}$ & $\begin{array}{c}\text { SMP } \\
\text { (junior bigh } \\
\text { school) }\end{array}$ & $\begin{array}{l}\text { SMA } \\
(\text { bigh } \\
\text { school }) \\
\end{array}$ & $\begin{array}{l}\text { D3/PT } \\
\text { (collegere) }\end{array}$ & & $\begin{array}{c}\text { Biasa } \\
\text { (ordinary) }\end{array}$ & $\begin{array}{l}\text { Pamong } \\
\text { (pamong) }\end{array}$ & $\begin{array}{c}\mathrm{RT} / \mathrm{RV} / \mathrm{Kadus} \\
(\mathrm{RT} / \mathrm{RW} \mid \\
\mathrm{Kaddus}) \\
\end{array}$ & $\begin{array}{c}\text { Ketua Klpk Tani } \\
\text { (Chairman of } \\
\text { Farmers Group) }\end{array}$ & $\begin{array}{l}\text { Lainnya } \\
\text { (others) }\end{array}$ \\
\hline 1 & Setren, Slogohimo & Hulu & $11 \%$ & $22 \%$ & $0 \%$ & $50 \%$ & $11 \%$ & $6 \%$ & $4,3 \%$ & $22 \%$ & $11 \%$ & $50 \%$ & $11 \%$ & $11 \%$ \\
\hline 2 & Karang, Slogohimo & Tengah & $13 \%$ & $19 \%$ & $13 \%$ & $31 \%$ & $19 \%$ & $6 \%$ & $4,5 \%$ & $56 \%$ & $6 \%$ & $19 \%$ & $13 \%$ & $6 \%$ \\
\hline 3 & Sugihan, Jatiroto & Hilir & $0 \%$ & $61 \%$ & $6 \%$ & $22 \%$ & $0 \%$ & $6 \%$ & $4,3 \%$ & $33 \%$ & $6 \%$ & $17 \%$ & $22 \%$ & $17 \%$ \\
\hline
\end{tabular}

Sumber (Source): Analisis Data Primer 2010 (Primary data analysis 2010)

Berdasarkan Tabel 2 terlihat pekerjaan tetap dan pekerjaan sampingan masyarakat baik di daerah hulu sampai hilir adalah petani. Pada Tabel 1, dijelaskan pula bahwa penutupan lahan di DAS Pengkol didominasi sawah dan tegal. Hal ini menunjukkan bahwa telah terjadi eksploitasi lahan, baik di daerah hulu maupun daerah hilir dari Sub DAS Keduang. Eksploitasi lahan yang berlebihan inilah yang dapat menimbulkan erosi dan sedimentasi di Waduk Gadjah Mungkur, sehingga diperlukan pengalihan pekerjaan diluar lahan pertanian.

Berdasarkan Tabel 3, terlihat pendidikan ratarata dari responden adalah berpendidikan SD sampai SMP, meskipun ada beberapa yang berpendidikan SMA dan perguruan tinggi. Pendidikan responden rata-rata rendah, yang tentu saja ini akan sangat mempengaruhi dalam berpikir, begitu juga dalam menerima hal-hal baru (Tribun News, 2011). Pendidikan yang rendah ini bisa disebabkan karena tingkat kesadaran masyarakat untuk bersekolah masih rendah atau kurangnya biaya untuk bersekolah.

\section{Kepemilikan Lahan}

Petani di Sub DAS Pengkol rata-rata memiliki lahan lebih dari satu bidang lahan. Minimal petani memiliki lahan tegal dan pekarangan. Rata-rata petani secara keseluruhan baik itu lahan tegal, sawah, pekarangan, dan lahan hutan mempunyai luas 0,33 Ha. Kepemilikan lahan mereka rata-rata sempit, apalagi rata-rata petani mempunyai tanggungan keluarga 4 orang.

Tanaman yang dibudidayakan adalah tanaman yang nilai ekonominya masih rendah, seperti jagung, ketela pohon, empon-empon dan lain sebagainya. Hasil panen hanya untuk memenuhi kebutuhan primer rumah tangga seperti makan, dan hanya sedikit panen yang dapat dijual. Secara lebih lengkap dapat dilihat pada Tabel 4.

\section{Sosial, Budaya, Nilai Tradisional dan Kelembagaan}

Kondisi sosial budaya, nilai tradisional dan kelembagaan di Sub DAS Pengkol secara jelas dapat dilihat pada Tabel 5 .

Tabel 4. Rata-rata Kepemilikan Lahan setiap Kepala Keluarga petani di Sub DAS Pengkol Table 4. Land Tenure Average of each head of family farmer in Pengkol Sub-Watershed

\begin{tabular}{llccccc}
\hline \multirow{2}{*}{$\begin{array}{c}\text { No } \\
\text { No) }\end{array}$} & $\begin{array}{c}\text { Desa (village) } \\
\text { Kecamatan } \\
\text { (sub district) }\end{array}$ & $\begin{array}{c}\text { Tegal } \\
\text { (dry land) }\end{array}$ & $\begin{array}{c}\text { Hutan } \\
\text { (forest) }\end{array}$ & $\begin{array}{c}\text { Sawah } \\
\text { (paddy field) }\end{array}$ & $\begin{array}{c}\text { Pekarangan } \\
\text { (grounds) }\end{array}$ & $\begin{array}{c}\text { Rata-rata } \\
\text { (average) }\end{array}$ \\
\hline 1 & $\begin{array}{l}\text { Desa Setren, } \\
\text { Kec Slogohimo }\end{array}$ & 0,42 & 0,30 & 0,36 & 0,40 & 0,35 \\
2 & $\begin{array}{l}\text { Desa Karang, } \\
\text { Kec Slogohimo }\end{array}$ & 0,37 & - & 0,23 & 0,46 & 0,37 \\
\hline & $\begin{array}{l}\text { Desa Sugihan, } \\
\text { Kec Jatiroto }\end{array}$ & 0,40 & - & 0,26 & 0,18 & 0,28 \\
\hline & Rata-rata (average) & 0,39 & 0,10 & 0,28 & 0,35 & 0,33 \\
\hline
\end{tabular}

Sumber (Source): Analisis data primer 2010 (Primary data analysis 2010) 
Tabel 5. Kondisi Sosial Budaya, Nilai Tradisional dan Kelembagaan di Sub DAS Pengkol

Table 5. Socio-Cultural, Traditional Values and Institutions in Pengkol Sub-Watershed

\begin{tabular}{|c|c|c|c|c|}
\hline No & $\begin{array}{c}\text { Uraian } \\
\text { (description) }\end{array}$ & $\begin{array}{l}\text { Desa (village) Setren, Kec } \\
\text { (sub district) Slogohimo }\end{array}$ & $\begin{array}{l}\text { Desa (village) Karang, Kec } \\
\text { (sub district) Slogohimo }\end{array}$ & $\begin{array}{l}\text { Desa (village) Sugihan, } \\
\text { Kec (sub district) Jatiroto }\end{array}$ \\
\hline 1 & $\begin{array}{l}\text { Sosial dan } \\
\text { Budaya (social } \\
\text { and cultural) }\end{array}$ & 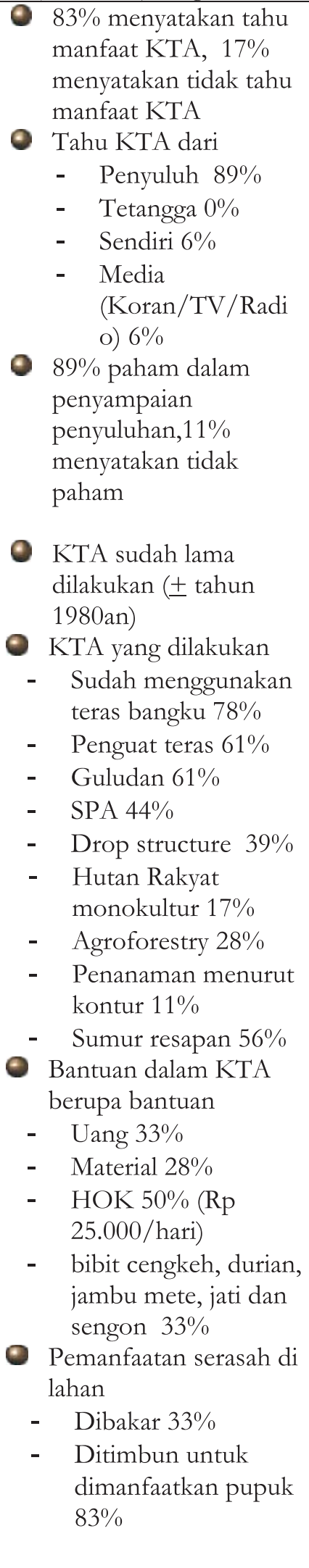 & 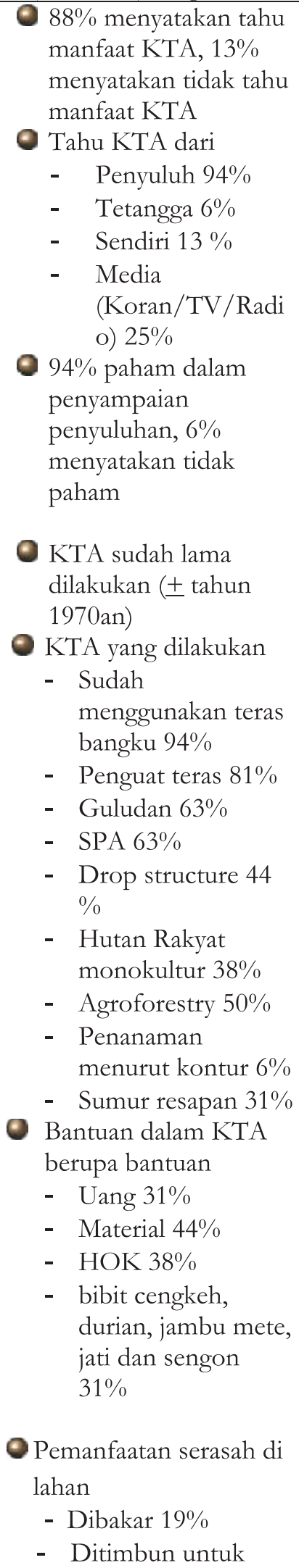 & 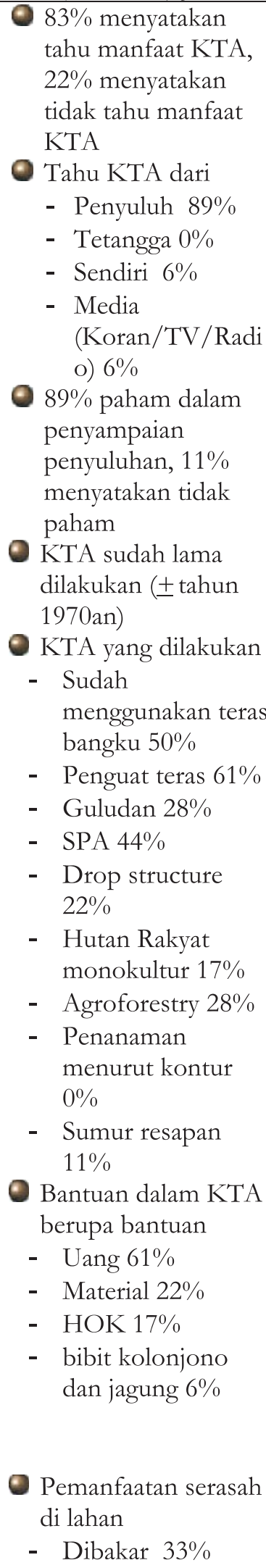 \\
\hline
\end{tabular}


Tabel 5. Lamjutan

Table 5. Continued

\begin{tabular}{|c|c|c|c|c|}
\hline No & $\begin{array}{c}\text { Uraian } \\
\text { (description) }\end{array}$ & $\begin{array}{c}\text { Desa (village) Setren, Kec } \\
\text { (sub district) Slogohimo }\end{array}$ & $\begin{array}{c}\text { Desa (village) Karang, Kec } \\
\text { (sub district) Slogohimo }\end{array}$ & $\begin{array}{l}\text { Desa (village) Sugihan, } \\
\operatorname{Kec} \text { (sub district) Jatiroto }\end{array}$ \\
\hline & & & $\begin{array}{l}\text { dimanfaatkan pupuk } \\
75 \%\end{array}$ & $\begin{array}{l}\text { - Ditimbun untuk } \\
\text { dimanfaatkan } \\
\text { pupuk } 56 \%\end{array}$ \\
\hline 2 & $\begin{array}{l}\text { Nilai } \\
\text { Tradisional } \\
\text { (traditional values) }\end{array}$ & $\begin{array}{l}\text { Budaya dan adat belum } \\
\text { ada, sehingga jika ada } \\
\text { masyarakat yang tidak } \\
\text { melakukan konservasi, } \\
\text { tidak ada sangsinya } \\
\text { atau dibiarkan saja } \\
\text { Budaya masih } \\
\text { berhubungan dengan } \\
\text { gotong royong bersih } \\
\text { desa, selamatan jika } \\
\text { panen raya. } \\
\text { Budaya yang } \\
\text { berhubungan dengan } \\
\text { konservasi tanah dan } \\
\text { air belum ada }\end{array}$ & $\begin{array}{l}\text { Budaya dan adat masih } \\
\text { bersifat kegiatan } \\
\text { gotong royong pada } \\
\text { saat pengolahan tanah } \\
\text { dan membuat } \\
\text { konservasi bagi petani } \\
\text { yang belum membuat. } \\
\text { Jika ada masyarakat } \\
\text { yang tidak melakukan } \\
\text { konservasi, tidak ada } \\
\text { sangsinya karena akan } \\
\text { dibuat secara } \\
\text { bergotong royong }\end{array}$ & $\begin{array}{l}\text { Budaya dan adat } \\
\text { masih bersifat } \\
\text { kegiatan gotong } \\
\text { royong pada saat } \\
\text { pengolahan tanah } \\
\text { dan membuat } \\
\text { konservasi bagi } \\
\text { petani yang belum } \\
\text { membuat. } \\
\text { Jika ada masyarakat } \\
\text { yang tidak melakukan } \\
\text { konservasi, tidak ada } \\
\text { sangsinya karena } \\
\text { akan dibuat secara } \\
\text { bergotong royong }\end{array}$ \\
\hline 3 & $\begin{array}{l}\text { Kelembagaan } \\
\text { (institutional) }\end{array}$ & $\begin{array}{l}\text { Kegiatan kelembagaan } \\
\text { yang terkait dengan } \\
\text { konservasi tanah yaitu } \\
\text { KKTA (Kelompok } \\
\text { Konservasi Tanah dan } \\
\text { Air), masih didominasi } \\
\text { dengan kegiatan arisan. }\end{array}$ & $\begin{array}{l}\text { Kegiatan kelembagaan } \\
\text { yang terkait dengan } \\
\text { konservasi tanah yaitu } \\
\text { KKTA (Kelompok } \\
\text { Konservasi Tanah dan } \\
\text { Air). Sebagai stimulus } \\
\text { agar petani datang } \\
\text { dilakukan kegiatan } \\
\text { arisan. }\end{array}$ & $\begin{array}{l}\text { Kegiatan } \\
\text { kelembagaan yang } \\
\text { terkait dengan } \\
\text { konservasi tanah } \\
\text { adalah kegiatan } \\
\text { kelompok tani. } \\
\text { Kegiatannya berupa } \\
\text { arisan dan } \\
\text { penyuluhan }\end{array}$ \\
\hline
\end{tabular}

Sumber (Source): Analisis Data Primer 2010 (Primary data analysis 2010)

Berdasarkan Tabel 5, pemahaman petani akan konservasi tanah dan air pada umumnya sudah baik. Menurut petani, manfaat konservasi tanah dan air adalah sebagai berikut : (1) dapat mengurangi erosi dan sedimentasi, (2) menjaga kelestarian alam, (3) dapat memelihara tanah, (4) menjaga kesuburan dan keawetan tanah, (5) mencegah sedimentasi yang berlebihan dari waduk Gajah Mungkur, (6) dapat menyimpan air, (7) meningkatkan hasil produksi pertanian.

Sementara itu ada juga petani yang tidak tahu manfaat konservasi tanah dan air. Dilihat dari prosentase yang paham dan yang tidak paham akan masalah konservasi tanah dan air, kurang lebih 83\%-88\% petani paham dan hanya sebagian kecil saja yang tidak paham. Hal ini dikarenakan petani tersebut tidak aktif mengikuti pertemuan rutin di desanya atau petani tersebut tidak pernah memperbarui informasi tentang pertanian. Di ketiga desa tersebut sudah dilakukan kegiatan pertemuan setiap bulan untuk memberi penyuluhan oleh penyuluh dan ketua kelompok tani. Materi penyuluhan yang disampaikan meliputi: (1) cara mengolah dan memelihara lahan agar tanah tidak banyak terbawa air (erosi), (2) cara membuat teras, (3) cara mengelola dan memanfaatkan lahan secara baik, (4) cara mengendalikan erosi dan sedimentasi dengan sipil teknis dan vegetative, membuat saluran air dan sengkedan, (5) penanaman tanaman keras, (6) pembuatan SPA, tampingan teras ditanami rumput, (7) pentingnya pupuk organik, (8) mengoptimalkan lahan dengan ditanami tanaman keras dan buah-buahan, (9) macammacam teknik konservasi, (10) penanggulangan hama dan penyakit, (11) pembuatan teras dan biopori untuk menahan laju erosi dan penyelamatan air, (12) penanaman rumput gajah, (13) cara membuat pupuk. 
Kondisi air minum di ketiga desa tersebut dalam keadaan baik, ini dilihat dari kelestarian pasokan air sepanjang tahun dan kondisi air yang jernih, sehingga kebutuhan air bersih di DAS Pengkol masih terpenuhi. Pada umumnya sumber air minum tersebut berasal dari sumur dan mata air. Di Desa Setren (hulu) dan Desa Karang (tengah) sumber air minum berasal dari sumber mata air sedangkan Desa Sugihan (hilir) berasal dari sumur.

\section{Pendapatan Keluarga}

Pendapatan keluarga di ketiga desa di Sub DAS Pengkol pada umumnya hampir sama yaitu diperoleh dari usaha tani dan luar usaha tani. Pendapatan dari usaha tani paling tinggi adalah Desa Sugihan, sedangkan pendapatan secara keseluruhan (mempertimbangkan pendapatan dari luar usaha tani) adalah Desa Karang. Pendapatan ini sudah dapat untuk memenuhi kebutuhan hidup layak petani, dimana Kebutuhan Hidup Layak Kabupaten Wonogiri adalah Rp. 772.931,00/ bulan/KK (BPS,2010). Untuk memenuhi kebutuhan sehari-hari, petani rata-rata mempunyai pekerjaan sampingan seperti buruh, tukang, pedagang dan lain-lain. Secara lebih jelas dapat di lihat pada Tabel 6 .

Tabel 6. Rata-rata Pendapatan Keluarga di Sub DAS Pengkol

Table 6. Average Family Income in Sub-Watershed Pengkol

\begin{tabular}{|c|c|c|c|c|c|c|c|c|c|c|}
\hline \multirow[t]{2}{*}{ No } & \multirow{2}{*}{$\begin{array}{c}\text { Desa } \\
\text { (village), } \\
\text { Kecamatan } \\
\text { (sub district), } \\
\text { Kabupaten } \\
\text { (regency) }\end{array}$} & \multicolumn{3}{|c|}{$\begin{array}{c}\text { Rata-rata Pendapatan } \\
\text { (average income) }\end{array}$} & \multicolumn{3}{|c|}{$\begin{array}{c}\text { Rata-rata Pengeluaran } \\
\text { (average expenditure) }\end{array}$} & \multirow[b]{2}{*}{$\begin{array}{l}\text { Pendapatan } \\
\text { Dari UT } \\
\text { (farm income) }\end{array}$} & \multirow{2}{*}{$\begin{array}{l}\text { Pendapatan } \\
\text { bersih/ } \\
\text { tahun (net } \\
\text { income/year) }\end{array}$} & \multirow{2}{*}{$\begin{array}{c}\text { Pendapatan } \\
\text { bersih/bulan } \\
\text { (net income/ } \\
\text { month) }\end{array}$} \\
\hline & & $\begin{array}{l}\text { Usaha tani } \\
\text { (farming) }\end{array}$ & $\begin{array}{c}\text { Luar } \\
\text { Usaha Tani } \\
\text { (non } \\
\text { farming) }\end{array}$ & $\begin{array}{l}\text { Total } \\
\text { (amount) }\end{array}$ & $\begin{array}{l}\text { Usaha tani } \\
\text { (farming) }\end{array}$ & $\begin{array}{l}\text { Rumah } \\
\text { tangga } \\
\text { (housebold) }\end{array}$ & $\begin{array}{l}\text { Total } \\
\text { (amount) }\end{array}$ & & & \\
\hline 1 & $\begin{array}{l}\text { Setren, } \\
\text { Slogohimo, } \\
\text { Wonogiri }\end{array}$ & 30.886 .401 & 8.935 .067 & 39.821 .467 & 9.031 .191 & 10.448 .563 & 19.479 .754 & 21.855 .210 & 20.341 .714 & 1.695 .143 \\
\hline 2 & $\begin{array}{l}\text { Karang, } \\
\text { Slogohimo, } \\
\text { Wonogiri }\end{array}$ & 27.211 .308 & 13.666 .667 & 40.877 .239 & 10.373 .167 & 10.373 .167 & 18.765 .405 & 18.819 .069 & 22.112 .569 & 1.842 .714 \\
\hline 3 & $\begin{array}{l}\text { Sugihan, } \\
\text { Jatiroto, } \\
\text { Wonogiri }\end{array}$ & 39.820 .810 & 8.981 .667 & 48.802 .477 & 16.482 .877 & 11.200 .075 & 27.682 .952 & 23.337 .933 & 21.119 .525 & 1.759 .960 \\
\hline
\end{tabular}

Sumber (Source): Analisis Data Primer 2010 (Primary data analysis 2010)

Pendapatan dari usaha tani diperoleh dari lahan tegal, sawah, hutan dan pekarangan. Pada lahan tegal didominasi tanaman padi, jagung dan ketela pohon. Padi dan jagung ditanam dua kali musim tanam, setelah itu lahan diberokan. Ketela pohon di Sub DAS Pengkol baru bisa dipanen setelah berumur dua tahun. Pada umumnya ketela pohon sudah dapat dipanen pada saat tanaman sudah berumur 9 (sembilan) bulan. Hal ini menunjukkan bahwa kondisi tanah sudah menurun kesuburannya.

Sawah tadah hujan ditanam dua kali musim tanam dan sawah irigasi ditanam tiga kali musim tanam. Di lahan pekarangan biasanya ditanami tanaman kayu-kayuan seperti jati, mahoni, bambu dan tanaman buah seperti mangga, pisang, mlinjo dan lainnya. Petani juga sudah memanfaatkan galengan dengan ditanami tanaman kacang panjang. Hasil panen dari lahan mereka lebih banyak dikonsumsi sendiri terutama padi. Untuk jagung dan ketela pohon biasanya sebagian dijual dan sebagian lagi dimakan sendiri sebagai campuran beras. Jagung dibuat nasi jagung, sedangkan untuk ketela pohon dibuat gaplek.

Tanaman kayu-kayuan seperti jati dan bambu, biasanya ditebang untuk memenuhi kebutuhan sendiri seperti untuk membangun rumah, sementara itu bambu biasanya untuk membuat kandang ternak. Mereka jarang menjual kayu dan bambu karena mereka menanam hanya untuk memenuhi kebutuhannya sendiri. Secara lebih jelas pola tanam dari setiap musim tanam pada setiap lahan dapat dilihat pada Tabel 7. 
Tabel 7. Jenis Tanaman yang di Tanam di Lahan Milik Petani di Sub DAS Pengkol

Table 7. Crops Planted in the Owned Land Farmers in Pengkol Sub-Watershed

\begin{tabular}{|c|c|c|c|c|c|}
\hline \multirow{2}{*}{$\begin{array}{l}\text { No } \\
\text { (No) }\end{array}$} & \multirow{2}{*}{$\begin{array}{l}\text { Desa(village) } \\
\text { Kecamatan } \\
\text { (sub district) }\end{array}$} & \multirow{2}{*}{$\begin{array}{l}\text { Jenis Lahan } \\
\text { (types of land) }\end{array}$} & \multicolumn{3}{|c|}{ Jenis Tanaman (types of crops) } \\
\hline & & & $\begin{array}{l}\text { Musim Tanam } 1 \\
\text { (cropping season 1) }\end{array}$ & $\begin{array}{l}\text { Musim Tanam } 2 \\
\text { (cropping season 2) }\end{array}$ & $\begin{array}{l}\text { Musim Tanam } 3 \\
\text { (cropping season 3) }\end{array}$ \\
\hline \multirow[t]{6}{*}{1} & \multirow[t]{6}{*}{$\begin{array}{l}\text { Setren, } \\
\text { Slogohimo }\end{array}$} & \multirow[t]{2}{*}{ Tegal } & $\begin{array}{l}\text { Jagung, buncis, ketela } \\
\text { pohon, bawang merah, } \\
\text { bawang putih }\end{array}$ & $\begin{array}{l}\text { Ketela pohon, } \\
\text { tembakau, wortel, } \\
\text { buncis, kacang } \\
\text { panjang, padi, } \\
\text { bawang merah }\end{array}$ & Ketela pohon \\
\hline & & & \multicolumn{3}{|c|}{$\begin{array}{l}\text { Cengkeh, alpukat, nangka, petai, durian, puspa, sengon, mahoni, jati, } \\
\text { rambutan, durian }\end{array}$} \\
\hline & & Hutan & Buncis, kentang & Tembakau & wortel, jagung \\
\hline & & Sawah & Padi, jagung & Padi & padi \\
\hline & & \multirow[t]{2}{*}{ Pekarangan } & $\begin{array}{l}\text { Jagung, buncis, kacang } \\
\text { tanah, tembakau }\end{array}$ & $\begin{array}{l}\text { Ketela pohon, } \\
\text { buncis, kacang } \\
\text { panjang }\end{array}$ & kunyit \\
\hline & & & \multicolumn{3}{|c|}{ Mahoni, jati, sengon, petai, cengkeh, durian, nangka, mlinjo, kelapa } \\
\hline \multirow[t]{6}{*}{2} & \multirow[t]{6}{*}{$\begin{array}{l}\text { Karang, } \\
\text { Slogohimo }\end{array}$} & \multirow[t]{2}{*}{ Tegal } & $\begin{array}{l}\text { Jagung, padi, ketela } \\
\text { pohon, }\end{array}$ & \multicolumn{2}{|l|}{$\begin{array}{l}\text { Ketela pohon, } \\
\text { kacang panjang, } \\
\text { kunyit }\end{array}$} \\
\hline & & & \multicolumn{3}{|c|}{ Sengon, jati, mahoni, cengkeh, jambu mete, kelapa, petai, kakao } \\
\hline & & Hutan & \multicolumn{3}{|c|}{ Menyadap pinus } \\
\hline & & Sawah & $\begin{array}{l}\text { Padi, jagung, ketela } \\
\text { pohon }\end{array}$ & Padi & padi \\
\hline & & \multirow[t]{2}{*}{ Pekarangan } & $\begin{array}{l}\text { Jagung, ketela pohon, } \\
\text { kacang panjang, jahe, } \\
\text { kunyit, kedelai }\end{array}$ & Ketela pohon & Ketela pohon \\
\hline & & & Kelapa, sengon, jati, n & $\begin{array}{l}\text { ahoni, cengkeh, durian, } \\
\text { pukat, kopi, rambutan }\end{array}$ & petai, kakao, mlinjo, \\
\hline \multirow[t]{5}{*}{3} & \multirow[t]{5}{*}{$\begin{array}{l}\text { Sugihan, } \\
\text { Jatiroto }\end{array}$} & \multirow[t]{2}{*}{ Tegal } & $\begin{array}{l}\text { Jagung, ketela pohon, } \\
\text { padi, kacang panjang }\end{array}$ & $\begin{array}{l}\text { Padi, kacang panjang, } \\
\text { kedelai, jagung }\end{array}$ & \\
\hline & & & \multicolumn{3}{|c|}{ Jambu mete, bambu, jati, mahoni } \\
\hline & & Sawah & $\begin{array}{l}\text { Padi, jagung, kacang } \\
\text { panjang, terong, bayam }\end{array}$ & $\begin{array}{l}\text { Padi, kacang panjang, } \\
\text { jagung }\end{array}$ & $\begin{array}{l}\text { Padi, kedelai, kacang } \\
\text { panjang, cabe }\end{array}$ \\
\hline & & \multirow[t]{2}{*}{ Pekarangan } & $\begin{array}{l}\text { Jagung, kunyit, ketela } \\
\text { pohon, kacang panjang }\end{array}$ & \multicolumn{2}{|l|}{ Kacang panjang } \\
\hline & & & $\begin{array}{r}\text { Jambu mete, pisang } \\
\text { sonoke }\end{array}$ & $\begin{array}{l}\text { jati, mahoni, rambutar } \\
\text { ing, johar, trembesi, m }\end{array}$ & $\begin{array}{l}\text { sengon, bambu, } \\
\text { ngga }\end{array}$ \\
\hline
\end{tabular}

Sumber (Source): Analisis Data Primer 2010 (Primary data analysis 2010) 


\section{Karakteristik Responden dalam Hubungan- nya dengan Pengelolaan DAS}

Karakteristik responden di daerah Sub DAS Pengkol pada umumnya adalah petani dengan usia produktif, mereka dapat diberdayakan untuk ikut serta dalam memperbaiki lingkungan. Secara umum mereka sudah memahami pentingnya konservasi, dan dampak yang diterima apabila tidak melakukan konservasi.

Menurut Suwarsono (2012) masyarakat merupakan pelaku sekaligus pengambil manfaat maupun dampak dalam pengelolaan sumberdaya alam di dalam suatu DAS. Sebagai pelaku yang aktif masyarakat mempunyai perilaku yang dapat mendukung upaya-upaya pengelolaan DAS, sebagai penikmat atau pengambil manfaat DAS yaitu pemanfaatan air permukaan dari sungai maupun sumur dibawah permukaan dan kesuburan tanah. Di lain pihak jika masyarakat memperburuk kondisi DAS, maka masyarakat akan menerima dampaknya.

Hal utama yang perlu dilakukan adalah menggerakkan petani dalam kegiatan-kegiatan terkait konservasi tanah. Masyarakat sebagai pemilik lahan berperan dalam mengelola lahan miliknya maupun sebagai pemegang keputusan mengubah fungsi lahannya (Suwarno, 2012). Dengan demikian masyarakat dapat mengolah tanah tanpa merusak lingkungan, mengkonservasi tanah secara baik sehingga dapat mengurangi erosi dan sedimentasi, serta menanam tanaman bernilai ekonomi tinggi. Selain itu perlu adanya kerjasama dengan pemuka masyarakat, instansi terkait, LSM dan yang berkepentingan dengan lingkungan dalam membangun daerah hulu. Hal ini karena pengelolaan daerah hulu (DAS hulu) tidak dapat dilakukan sendiri-sendiri.

Partisipasi aktif masyarakat tidak akan muncul tanpa disertai adanya pemberdayaan masyarakat berupa penciptaan kondisi yang memungkinkan masyarakat mampu membangun diri dan lingkungan secara mandiri. Hal lain yang tidak kalah pentingnya adalah perlu adanya penghargaan (reward) bagi masyarakat yang telah melakukan konservasi sesuai dengan kaedah konservasi sehingga masyarakat semakin terpacu untuk melakukan kegiatan-kegiatan yang dapat mengurangi erosi dan sedimentasi di daerah hulu.

\section{KESIMPULAN DAN SARAN}

1. Karakteristik masyarakat hulu pada umumnya adalah petani dengan umur produktif serta sudah paham akan manfaat dan dampak konservasi tanah.

2. Pada umumnya petani mempunyai lahan lebih dari satu bidang lahan yang luasnya sempit dan ditanami tanaman tumpangsari, empon-empon dan tanaman berkayu.

3. Pendapatan keluarga ketiga desa sudah berada diatas Kebutuhan Hidup Layak.

4. Perlu adanya pembinaan yang lebih baik dan terstruktur untuk membangun daerah hulu bersama masyarakat sehingga perlunya adanya kerjasama multipihak dari pemerintah, LSM, civitas akedemika dan instansi terkait lainnya untuk melakukan pemberdayaan masyarakat agar masyarakat lebih mandiri dan tidak tergantung hanya dari sektor pertanian saja.

5. Perlu adanya penghargaan (reward) untuk masyarakat hulu yang telah melakukan kegiatan konservasi tanah.

\section{DAFTAR PUSTAKA}

Atmojo, S.W. (2008). Peran agroforestry dalam menanggulangi banjir dan longsor $D A S$. Disajikan dalam Seminar Nasional Pendidikan Agroforestry Sebagai Strategi Menghadapi Pemanasan Global di Fakultas Pertanian, UNS. Solo, 4 Maret 2008. Www. Suntoro.staff.uns.ac.id / files/.../ 3agroforestri-banjir-dan-longsor-das.

Asdak, C. (2002). Hidrologi dan pengelolaan Daerah Aliran Sungai. Yogyakarta: Gadjah Mada University Press.

BPS. (2009). Kabupaten Wonogiri dalam angka. Wonogiri : BPS Kabupaten Wonogiri.

Departemen Kehutanan. (2009). Lampiran peraturan Direktur Jenderal Rehabilitasi Laban dan Perbutanan Sosial tentang Pedoman Monitoring dan Evaluasi Daerah Aliran Sungai No: P.04/V-SET/2009 Tanggal: 05 Maret 2009. Jakarta: Departemen Kehutanan. 
Departemen Kehutanan. (2009). Keputusan Menteri Kebutanan Republik Indonesia. Nomor SK.328/Menhut-II/2009. Tentang penetapan Daerah Aliran Sungai (DAS) dalam rangka Pembangunan Jangka Menengab (RPJM) Tahun 2010-2014. Jakarta : Departemen Kehutanan

Eka, K. I., \& S. Kukuh. (2008). Sedimentasi waduk dan kinerja Pemda. Wawasan, 6 Februari 2008.

Kartodihardjo, H., K. Murtilaksono, \& Untung, S. (2004). Institusi pengelolaan Daerah Aliran Sungai: konsep dan pengantar analisis kebijakan. Bogor : Fakultas Kehutanan, Institut Pertanian Bogor.

Paimin, Sukresno, \& Purwanto. (2006). Sidik cepat degradasi. Sub Daerah Aliran Sungai (Sub DAS). Pusat Penelitan dan Pengembangan Hutan dan Konservasi Alam. Bogor : Badan Penelitian dan Pengembangan Kehutanan.

Paimin, Sukresno, Tyas, M. B., \& Purwanto. (2002). Monitoring dan evaluasi Daerah Aliran Sungai dalam perspektif diagnosa kesehatannya. Prosiding Seminar Monitoring dan Evaluasi Pengelolaan DAS. Surakarta, 23 Desember 2002. Jakarta : Departemen Kehutanan.

Paimin. (2009). Laporan akbir hasil penelitian tabun 2003-2009. Usulan Kegiatan Hasil Penelitian (UKP). Sistem karakterisasi Daerah Aliran Sungai. Solo : Balai Penelitian Kehutanan Solo, Departemen Kehutanan.
Sarwono, \& Jonathan. (2006). Metode penelitian kuantitatif dan kualitatif. Yogyakarta: Graha Ilmu.

SCBFWM. (2013). Pengelolaan DAS berbasis masyarakat. Http://www.scbfwm. org/2013/02/13/pengelolaan-dasberbasis-masyarakat.html.

SCBFWM. (2010). Mengenal Daerah Aliran Sungai dan permasalahannya. proyek penguatan pengelolaan hutan dan DAS berbasis masyarakat. Buletin DAS nomor 1 September 2010. Http://www.Scbfwm.org.

Sejarah Waduk Gadjah Mungkur. (2012). Http://epriant.com /2012/01/ sejarahwaduk-gajah-mungkur.html.

Suwarno, J. (2012). Peran serta masyarakat dalam pengelolaan DAS. Buletin Bina DAS. September 2012. Http:/ / www.scbfwm.org.

Tim Peneliti BP2TPDAS-IBB. (2004). Pedoman Monitoring Dan Evaluasi Pengelolaan Daerah Aliran Sungai (edisi revisi 2004). Surakarta : BP2TPDAS- IBB Surakarta.

Tim Koordinasi Pengelolaan Sumber Daya Air. (2003). Pedoman teknis pengelolaan Daerah Aliran Sungai terpadu. Draft Final Sekretariat TKPSDA 2003. Www.Bappenas.go.id.

Tribun News. (2011). Tingkat pendidikan bisa mengendalikan penduduk. Jumat, 30 Desember 2011. http://m.tribunnews. com/2011/12/30/tingkat- pendidikanbisa-mengendalikan-penduduk. 